\title{
Front Matter: Volume 1514
}

, "Front Matter: Volume 1514," Proc. SPIE 1514, 15th International Conference on Infrared and Millimeter Waves, 151401 (1 December 1990); doi: $10.1117 / 12.2301411$

Event: 15th International Conference on Infrared and Millimeter Waves, 1990, SPIE. Orlando, FL, United States 


\section{Frerking, Presider}

M1.1 ADVANCES IN MILLIMETER WAVE EXTENDED INTERACTION KLYSTRONS AND TRANSMITTER SUBSYSTEMS - (Invited) Maurice Viant and Man Wong, Varian Canada, Inc., 45 River Drive, Georgetown, Ontario, Canada L7G 2J4

M1.2 A COMPACT PHASE-LOCKED HARMONIC GYROTRON FOR MODERN MILLIMETER WAVE RADAR APPLICATIONS - H. Guo, Y. Carmel, V.L. Granatstein, Laboratory for Plasma Research, U of Maryland, College Park, MD 20742

M1.3 SIMULATION FOR THE DESIGN OF A FREQUENCY STABLE VIRCATOR - John Kim and S.P. Kuo, Weber Research Institute, Polytechnic U, Route 110, Farmingdale, NY 11735

M1.4 DESIGN AND EXPERIMENTS OF AUTO-RESONANT PENIOTRON OSCILLATOR - K. Yokoo, S. Musyoki, Y. Nakazato, N. Sato and S. Ono, Research Institute of Electrical Communication, Tohoku U, Sendai 980, Japan

M1.5 EXPERIMENTAL INVESTIGATION OF FREQUENCY STABILITY OF A QUASIOPTICAL POWER COMBINER - Ge Jun-xiang, Li Si-fan, Chen Yi-yuan, Department of Radio Engineering, Southeast U, Nanjing 210018 P.R.China

M1.6 A NEW KIND OF COMPOUND QUASI-OPTICAL POWER COMBINER - Ge Junxiang, Li Si-fan, Chen Yi-yuan, Department of Radio Engineering, Southeast U, Nanjing 210018 P.R.China

M1.7 COMPARISON BETWEEN CAVITY STABILIZED FET OSCILLATORS - O.A. Elnor, A. Jacob and K. Schünemann, Technische Universität Hamburg-Harburg, Arbeitsbereich Hochfrequenztechnik, Postfach 9010 52, D-2100 Hamburg 90, West Germany

M1.8 A TWO-DIMENSIONAL PERTURBATION TECHNIQUE TO MODEL ION-IMPLATED GaAs MESFET FOR MILLIMETER-WAVE SYSTEMS - Eric Donkor and Faquir C. Jain, Electrical and Systems Engineering Department, U of Connecticut, Storrs, CT 062693147

15th International Conference on Infrared and Millimeter Waves, edited by Richard J. Temkin, Proc. of SPIE Vol. 1514, 151401 - @ (1990) 2017 SPIE · CCC code: 0277-786X/17/\$18 · doi: 10.1117/12.2301411 


\section{M.N. Afsar, Presider}

M2.1 SUPERCONDUCTING ENERGY GAP AND NORMAL STATE INFRARED PROPERTIES OF HIGH $\mathrm{T}_{c}$ SUPERCONDUCTORS - (Invited) - Z. Schlesinger, R.T. Collins, F. Holtzberg, C. Feild and S.H. Blanton, IBM T.J. Watson Research Center, Yorktown Hights, NY 10598; U. Welp ${ }^{1,2}$, G.W. Crabtree' ${ }^{2}$, Y. Fang ${ }^{2}$, J.Z. Liu $^{3}$ and D.G. Hinks, ${ }^{1}$ Science \& Technolog Center for Superconductivity; ${ }^{2}$ Materials Science Div, Argonne Natl Lab, Argonne, IL 60439; ${ }^{3}$ Dept of Physics, U of California, Davis CA 95616

M2.2 HIGH TEMPERATURE SUPERCONDUCTIVITY SPACE EXPERIMENT (HTTSSE): PASSIVE MMW DEVICES - (Invited) - S.A. Wolf, M. Nisenoff, D.U. Gubser, J.C. Ritter, G. Price, NRL, Washington, DC 20375

M2.3 FERMIOLOGY OF HIGH TEMPERATURE SUPERCONDUCTORS - M. Goiran, H. Rakoto, J.C. Ousset, J.P. Ulmet, J. Leotin and S. Askenazy, Laboratoire de Physique des Solides et Service de Champs Intenses, 31077 Toulouse-Cedex, France; M.S. Osofsky, D.B. Chrisey, J.S. Horwitz, E.F. Skelton, R.J. Soulen, Jr. and S.A. Wolf, NRL Washington, DC

M2.4 USE OF HIGH TEMPERATURE SUPERCONDUCTING MICROSTRIPLINES FOR IR LIGHT DETECTION - (Invited) - U. Strom, J.C. Culbertson, H.S. Newman, J.M. Pond, D.B. Chrisey, J.S. Horowitz and S.A. Wolf, NRL, Washington, DC 20375

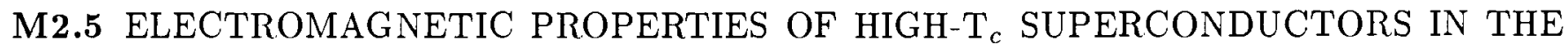
PRESENCE OF HIGH-AMPLITUDE RF MAGNETIC FIELDS - C.L. Bohn, J.R. Delayen, W.L. Kennedy and C.T. Roche, Argonne Natl Lab, Argonne, IL 60439

M2.6 THE MEASUREMENT OF PENETRATION DEPTH AND SURFACE RESISTANCE OF BULK YBCO SUPERCONDUCTOR BY USING MICROSTRIP RESONATOR METHOD - S.Z. Cai and W. Wu, Dept of EE, Fudan Univ, Shanghai 200433, PRC

M2.7 PRECISION SUBMILLIMETER-WAVE LASER REFLECTOMETRY OF METALS AND SUPERCONDUCTORS - P.P. Woskov, D.R. Cohn, MIT Plasma Fusion Center, Cambridge, MA 02139; S.C. Han, Xsirius Superconductivity Inc, 7590 East Gray Road, Scottsdale, AZ 85260; R.H. Giles and J. Waldman, Univ of Lowell Res Foundation, 450 Aiken St, Lowell, MA 01854 
M3.1 A $110 \mathrm{GHz}$ RADIOMETER FOR STRATOSPHERIC OZONE MONITORING - Heikki Valmu, Olli Koistinen and Antti Räisänen, Helsinki Univ of Technology, Espoo, Finland

M3.2 A NUMERICAL SIMULATION OF THE TRACE GAS PROFILING FOR MILLIMETER/ SUB-MILLIMETER WAVE SPECTROSCOPY - Satoshi Ochiai and Harunobu Masuko, Kashima Space Research Center, Hirai, Kashima Ibaraki 314 Japan

M3.3 FAR INFRARED FT SPECTROSCOPY AND ITS IMPORTANCE FOR REMOTE SENSING - M. Birk, D. Hausamann, Inst for Optoelectronics, German Aerospace Research Est., 8031 Oberpfaffenhofen, FRGermany

M3.4 ADVANCED MICROWAVE PRECIPITATION RADIOMETER (AMPR) TEST \& EVALUATION - J.A. Galliano, GTRI, Georgia I of Technology, Atlanta, Georgia 30332

M3.5 CONTROLLED EXPERIMENTS FOR WAVE-PARTICLE INTERACTIONS IN THE MAGNETOSPHERE WITH ARECIBO RADIO FACILITY - M.C. Lee, K.L. Koh, F.M. Groves and C. Yoo, MIT Plasma Fusion Center, Cambridge, MA 02139; S.P. Kuo, Weber Research Institute, Polytechnic U, Farmingdale, NY 11735

M3.6 CALCULATIONS OF MILLIMETER WAVE DEPOLARIZATION DUE TO MELTING LAYER AND RAIN - Wei Zhang and Erkki Salonen, Helsinki U of Technology, Radio Laboratory, Otakaari 5A, SF 02150 Espoo, Finland

M3.7 BRAGG SCATTERING MEASUREMENT OF ATMOSPHERIC PLASMA DECAY S.P. Kuo and Y.S. Zhang, Polytechnic U, Farmingdale, NY 11735; M.C. Lee, MIT Plasma Fusion Cente, Cambridge, MA 02139

M3.8 REENTRY PLASMA BOUNDARY LAYER MEASUREMENTS AT MILLIMETER WAVE FREQUENCIES - James L. Kurtz, James A. Scheer, Rob G. Pauley, GTRI, Atlanta GA 30332; Jim Grosch and Joe Seals, Electromagnetic Sciences, Norcross, GA

M3.9 A WATER VAPOUR AND TEMPERATURE ATMOSPHERIC VERTICAL SOUNDER BETWEEN 110 AND 190 GHz: OBSERVING CAMPAIGNS IN PROSPECT - P. Abba, G. Beaudin, A. Deschamps, P. Encrenaz, M. Gheudin, J.R. Jégou, C. Prigent, G. Ruffié, Observatoire de Meudon, 92100 Meudon, France

M3.10 STUDIES OF THE PRESSURE-BROADENED ATMOSPHERIC OXYGEN SPECTRUM WITH AN AUTOMATED MILLIMETER-WAVE RESONANCE SPECTROMETER H.J. Liebe, R. DeBolt and G. Hufford, Inst for Telecomm Sci., S1, 325 Broadway, Boulder, $\mathrm{CO} 80303$ 


\section{J. Walsh, Presider}

M4.1 DEMONSTRATION AND APPLICATIONS OF A FIR CAVITY DUMP OUTPUT COUPLER AT THE UC SANTA BARBARA FEL FACILITY - J.P. Kaminski, D. Enyeart and D. White, Quantum Inst and Ctr for FEL Studies, U of California, Santa Barbara, CA 93106

M4.2 HARMONIC OPERATION OF A FREE ELECTRON LASER - B. Levush, P.E. Latham and T.M. Antonsen, Jr., Lab for Plasma Research, U of Maryland, College Park, MD 20742

M4.3 POWER JITTERING IN FEL OSCILLATORS CAUSED BY INTERNAL MODULATION - Spilios Riyopoulos, Science Appl Intl Corp, P.O. Box 1303, McLean, VA 22102

M4.4 MILLIMETER-WAVE FREE-ELECTRON MASER EXPERIMENTS - F. Hartemann*, T.S. Chu, B.G. Danly, P. Papavaritis and R.J. Temkin, MIT Plasma Fusion Center, Cambridge, MA 02139; *TTE, 78141 Vélizy France; G. Mourier, G. Faillon, T. Trémeau and M. Bres, TTE, 78141 Vélizy France

M4.5 A HIGH POWER FREE-ELECTRON MASER OSCILLATOR - T.S. Chu, F. Hartemann*, P. Papavaritis, B.G. Danly, R.J. Temkin, MIT Plasma Fusion Center, Cambridge, MA 02139; *TTE, 78141 Vélizy France; G. Mourier, G. Faillon, T. Trémeau and M. Bres, TTE, France

M4.6 MICROWAVE FREQUENCY MODIFICATION USING PLASMAS - Mark Rader, Fred Dyer and Igor Alexeff, Univ of Tennessee, Elect and Cmptr Engr Dept, 206 Ferris Hall, Knoxville, TN 37996

M4.7 A QUASI-OPTICAL ORBITRON MASER - Fred Dyer, Mark Radar and Igor Alexeff, The Univ of Tennessee, Elect and Cmptr Engr Dept, 206 Ferris Hall, Knoxville, TN 37996

M4.8 SPACE-CHARGE WAVE THEORY OF FREE ELECTRON LASER - Liu Shenggang, Univ of Electron. Science and Tech of China, Chengdu, PRC

M4.9 INVESTIGATION ON THE MECHANISM OF OBITRON RADIATION - Ouyang Zhengbiao, Room 303, Bldg. Yunyan, Shanzhen Univ, Shenzhen 518060, PRC 
M5.1 MILlimETER AND SUBMILLIMETER WAVE MULTIPLIERS - A COMPARATIVE ANALYSIS - (Invited Keynote) - Timo J. Tolmunen and Margaret A. Frerking, Jet Propulsion Lab, Pasadena, CA 91109

M5.2 QUANTUM WELL DIODE FREQUENCY MULTIPLIER STUDY - R.J. Hwu, Department of Electrical Engineering, U of Utah; N.C. Luhmann, Jr., Department of Electrical Engineering, U of California, Los Angeles, CA

M5.3 A THREE-REGION ANALYTICAL MODEL FOR InP MISFET's OPERATING IN THE MILLIMETER-WAVE REGIME - F. Jain, X. Bao and E. Donkor, Department of Electrical and System Engineering, U-157, U of Connecticut, 260 Glenbrook Road, Storrs, CT 06269-3157; K. Kalonia, Maxim Integrated, 510 N. Pastoria, Sunnyvale, CA 94086

M5.4 QUANTUM WELL INJECTION TRANSIT TIME (QWITT) DIODE OSCILLATORS - V.K. Reddy, A.J. Tsao, S. Javalagi, G.K. Kumar, D.R. Miller and D.P. Neikirk, Department of Electrical and Computer Engineering, U of Texas at Austin, Austin, TX 78712

M5.5 SUBMILLIMETER WAVE SUPERCONDUCTING FLUX-FLOW OSCILLATOR - K. Sakai, Y. Konishi, H. Kobayashi, Department of Applied Physics, Osaka U, Suita, Osaka 565, Japan; J. Inatani, Nobeyama Radio Observatory, National Astronomical Observatory, Nobeyama, Nagano 384-13, Japan; S. Kodaira, Kisarazu National College of Technology, Kisarazu, Chiba 292, Japan; K. Yoshida, Department of Electronics, Kyushu U, Fukuoka. 812 , Japan

M5.6 THEORETICAL ANALYSIS \& EXPERIMENTAL VERIFICATION OF WIDEBAND TUNABLE RADIAL LINE MILLIMETER WAVEGUIDE VOLTAGE CONTROLLED OSCILLATORS - Nizar Sultan, Telesat Canada, 1601 Telesat Court, Gloucester, Ontario K1B 5P4 Canada.

M5.7 MILLIMETER WAVE QW1TT DIODE OSCILLATOR - Hayat M. Khan, Jangammeth, P.O. - Falaic Numa, Hyderabad - 500253 - A.P. India

M5.8 GENERATION OF MILLIMETER WAVE RADIATION BY OPTICAL MIXING IN FETs INTEGRATED WITH PRINTED CIRCUIT ANTENNAS - D.V. Plant, D.C. Scott, D.C. Ni and H.R. Fetterman, Dept of EE, UCLA, Los Angeles, CA 90024 
SESSION M6

Monday PM

HIGH $\mathrm{T}_{c}$ SUPERCONDUCTORS II

Dec. 10

\section{Z. Schlesinger, Presider}

M6.1 MILLIMETER WAVE SURFACE IMPEDANCE AND FAR INFRARED REFLECTIVITY OF EPITAXIALLY GROWN HIGH $\mathrm{T}_{c}$ FILMS - (Invited Keynote) - N. Klein, H. Chaloupka, G. Müller, S. Orback H. Piel, Bergische Univ Wuppertal, FRG; H. Soltner, U. Poppe, K. Urban, Inst für Festkörperforschung, FRG; B. Roas, L. Schultz, Siemens AG, Erlangen; J. Geerk, F. Vassenden, Inst Nukleare Festkörperphysik; P. Berberich, H. Kinder, Technische Univ München, FRG; K.F. Renk, J. Schützmann, Univ Regensburg, FRG

M6.2 FAR INFRARED TRANSMITTANCE STUDIES OF HIGH $\mathrm{T}_{c}$ SUPERCONDUCTING THIN FILMS - L. Lesyna*, R. Budhani, D. DiMarzio*, G. Williams, H. Wiesmann, Brookhaven Natl Lab, Upton, NY; *Grummen Corp Res Ctr, Bethpage, NY

M6.3 INFRARED DETECTION BY Tl-Ba-Ca-Cu-0 SUPERCONDUCTING FILMS - G. Schneider, H. Lengfellner, J. Betz, K.F. Renk and W. Prettl, U of Regensburg, D8400 Regensburg, FRG

M6.4 NERNST EFFECT BY PULSED INFRARED LASER HEATING IN Tl-Ba-Ca-Cu-0 HIGH-T $\mathrm{T}_{c}$ SUPERCONDUCTING FILMS - H. Lengfellner, A. Schnellbögl, J. Betz, K.F. Rent and W. Prettl, Univ Regensburg, FRG

M6.5 REFLECTION-ABSORPTION SPECTRA IN Bi(Pb)-Sr-Ca-Cu-O SUPERCONDUCTOR - L. Zhong, J. Cai and H. Tang, Anhui Inst of Optics and Fine Mechinics, Academia Sinica, Hefei 230031, PRC

M6.6 HIGH-FIELD EPR IN Gd-DOPED $\mathrm{Bi}_{2} \mathrm{Sr}_{2} \mathrm{CaCu}_{2} \mathrm{O}_{8+y}$ and $\mathrm{GdBa}_{2} \mathrm{Cu}_{3} \mathrm{O}_{7-d}-\mathrm{F}$. Scheerlinck, A. Stesmans, K. DeMey, P. DeGroot, L. Van Bockstal, P. Janssen, F. Herlach and J. Witters, Katholieke Univ Leuven, Celestijnenlaan 200 D, B-3030 Leuven

M6.7 SubMMW DIELECTRIC PROPERTIES OF HIGH-- $\mathrm{T}_{c}$ SUPERCONDUCTORS AND RELATED MATERIALS - (Invited Keynote) - A.A. Volkov, B.P. Gorshunov, G.V. Kozlov, O.I. Sirotinskii, Academy of Sciences of the USSR, Moscow, USSR

M6.8 MILLIMETER WAVE TRANSMISSION MEASUREMENTS OF HIGH $\mathrm{T}_{c}$ SUPERCONDUCTING THIN FILMS - F.A. Miranda, W.L. Gordon, Case Western Reserve Univ, Cleveland, OH; K.B. Bhasin and J.D. Warner, NASA Lewis Research Ctr, Cleveland, OH 
SESSION M7

Monday PM

ASTRONOMY

Dec. 10

F. Kneubühl, Presider

M7.1 A $6 \mathrm{GHz}$ HEMT LOW-NOISE COOLED AMPLIFIER FOR A RADIOASTRONOMICAL SUBMILLIMETER HETERODYNE RECEIVER - Clélia Robert and M. Gheudin, Dept de Radioastronomie millimétrique (DEMIRM), Observatoire de Meudon, 92195 Meudon, France

M7.2 NONLINEAR RESPONSE OF A 3-ELEMENT STRESSED Ge:Ga PHOTOCONDUCTOR ARRAY FOR THE INFRARED TELESCOPE IN SPACE - N. Hiromoto and T. Itabe, Communications Research Lab, Koganei, Tokyo 184, Japan; H. Okuda and Shibai, Inst of Space and Astronautical Science, Sagamihara, Kanagawa 229, Japan; H. Matsuhara Nagoya Univ, Tikusa-ku, Nagoya 464, Japan

M7.3 AN INFRARED CAMERA WITH A HgCdTe 128x128 ARRAY ON THE CRL 1.5 MTELESCOPE - N. Hiromoto, H. Takami, T. Itabe and T. Aruga, Communications Research Lab, Koganei, Tokyo 184, Japan; T. Aoki, U of Tokyo, Bunkyo-ku, Tokyo 113, Japan; S. Sato and Y. Yamashita, Natl Astronomical Observatory Japan, Mitaka, Tokyo 181, Japan; M. Tanaka, Univ of Tokyo, Mitaka, Tokyo 181, Japan

M7.4 THE CRL 34-M RADIO TELESCOPE AT KASHIMA AND THE FIRST RESULT OF KNIFE (KASHIMA-NOBEYAMA INTERFEROMETER) -- Hiroshi Takaba, Yasuhiro Koyama, Michito Imae, Communications Research Laboratory; Makoto Miyoshi, U of Tokyo; Noriyuki Kawaguchi and Masaki Morimoto, Nobeyama Radio Observatory

M7.5 A $380 \mathrm{GHz}$ RECEIVER FRONT-END FOR A BALLOON-BORNE RADIOASTRONOMICAL EXPERIMENT - O. Perrin, G. Beaudin, P. Encrenaz, Laboratoire de Radioastronomie Millimétrique, Observatoire de Meudon, 92190 Meudon, France

M7.6 SECONDARY-MIRROR CHOPPING IN A BALLOON-BORNE TELESCOPE FOR FIR IMAGING, RADIOMETRY AND SPECTROMETRY OF THE GALACTIC CYGNUS REGION - A. Holenstein, G. Schenker and F.K. Kneubühl, Infrared Phsycis Lab FTH, CH-8093 Zurich, Switzerland; D. Huguenin, Geneva Observatory, CH-1290 Sauverny, Switzerland

M7.7 IN-SPACE EXPERIMENTS FOR MICROWAVE/MILLIMETER-WAVE POWER TRANSMISSION - K. Chang, M. Pollock, K. Mummer, J. McCleary, Bing Wei, Dept of Elec Engr, Texas A\&M University, College Station, TX 77843-5285 


\section{Alexeff, Presider}

M8.1 OPERATION OF THE GRATING-COUPLED OSCILLATOR AT SUBMILLIMETER WAVELENGTHS - (Invited) - E. Price, J. Walsh, Dartmouth College, Hanover, NH; M. Kimmitt, U of Essex, Colchester, UK

M8.2 IMPROVED AMPLIFIER PERFORMANCE OF THE NRL UBITRON - D.E. Pershing, R.H. Jackson, H. Bluem and H. Freund, Naval Research Lab, Washington, DC 20375

M8.3 EXPERIMENTAL DEVELOPMENT OF A MILLIMETER WAVE FREE ELECTRON LASER - D.J. Radack, S.W. Bidwell, T.M. Antonsen, Jr., Y. Carmel, W.W. Destler, V.L. Granatstein, P.E. Latham, B. Levush, I.D. Mayergoyz, J. Rodgers and Z.X. Zhang, Lab of Plasma Res, U of MD, College Pk, MD 20742

M8.4 H-Q BRAGG RESONATOR CARM EXPERIMENTS ON A LONG-PULSE ELECTRON BEAM ACCELERATOR - J.J. Choi, R.M. Gilgenbach and T.A. Spencer, Intense Energy Beam Interaction Lab, U of Michigan, Ann Arbor, MI 48109

M8.5 EXPERIMENTS ON RF GENERATION IN THE 0.7-6 MM WAVELENGTH RANGE - V.A. Bogachenkov, V.A. Papadichev, I.V. Sinilschikova, O.A. Smith, Lebedev Phys Inst Leninsky Prospect 53, 117924 Moscow, USSR

M8.6 HARMONIC UBITRON A MPLIFIER EXPERIMENT - R.H. Jackson, NRL, Code 6840, Washington, DC 20375; H. Blıem, *Lab for Plasma Res, Univ of MD, College Pk, MD 20742; D.E. Pershing, Mission Res Corp, Newington, VA 22122; H.P. Freund, Sci Appl Intl Corp, McLean, VA 22102; *V.L. Granatstein

M8.7 A PLASMA-BASED SOURCE OF PULSED MICROWAVE AND MILLIMETER WAVELENGTH RADIATION - R. Liou, H. Figueroa, A.H. McCurdy, U of So. California, Los Angeles, CA 90089; G. Kirkman-Amemiya, Integrated Applicd Physics, Inc, Arcadia, CA; R.J. Temkin, MIT Plasma Fusion Center; H. Fetterman, UCLA, Dept of Elec Engr; M.A. Gundersen, U of So. California, Los Angeles, CA 90024 


\section{E. Reedy, Presider}

T1.1 MILLIMETER RADIOMETER SPECTROMETERS FOR SPACE - William J. Wilson, Kumar Chandra, Jet Propulsion Lab, CA Inst. Tech., Pasadena, CA 91109

T1.2 DEVELOPMENT OF A $95 \mathrm{GHz}$ AIRBORNE RADAR MEASUREMENT SYSTEM T.L. Lane, D.W. Galloway, R.G. Pauley, GTRI, Georgia I of Technology, Atlanta, GA 30332; W.C. Parnell, 3246th Test Wing, Eglin AFB, FL 32345

T1.3 OPTIMIZED LADAR/RADAR SYSTEM FOR DETECTION AND TRACKING - J. Gavan and A. Peled, Electrical and Electronics Department, Center for Technological Education Holon, Holon 58368, Israel

T1.4 DOPPLER RADAR STUDIES AT $140 \mathrm{GHz}$ - U.H.W. Lammers, R.A. Marr, J.B. Morris, Rome Air Development Center, Hanscom AFB, MA

T1.5 APPLICATIONS OF HIGH-TEMPERATURE SUPERCONDUCTORS IN MILLIMETERWAVE COMPONENTS AND CIRCUITS - Asu R. Jha, Technical Director, Jha Technical Consulting Services, Cerritos, CA 90701

T1.6 $95 \mathrm{GHz}$ HIGH POWER COHERENT RADAR (HIPCOR-95) HIGH RANGE RESOLUTION MEASUREMENTS - T.L. Lane, R.G. Pauley, J.A. Scheer, GTRI, GA Inst. Tech., Atlanta, GA 30332; M. Christian, U.S. Army Missile Command, Redstone Arsenal, AL 35898

T1.7 MEASUREMENT OF COHERENCE BANDWIDTH FOR AN URBAN MILLIMETER WAVE MOBILE RADIO LINK - R.S. Cole and H.J. Thomas, U College London, Torrington Place, London WC1E $7 \mathrm{JE}$

T1.8 A 8-1000 GHz VECTOR NETWORK ANALYZER - P. Goy, AB Millimetre, 61-71 rue B. Frachon, Z.I. du Prunay, 78500 Sartrouville, France; M. Gross and J.M. Raimond, Laboratoire de Spectroscopie Hertzienne de l'Ecole normale supérieure, 24 rue Lhomond, 75231 Paris Cedex 05, France

T1.9 60 GHz DOWNCONVERTER - M. Sholley, L. Shaw, T. Best, D. Brunone, B. Brunner, E. Freitas, M. Tan, B. Allen, K. Tan, B. Nelson, Y. Ohm, TRW, Communication Laboratory, One Space Park, R8/2731, Redondo Beach, CA 90278 


\section{J.R. Birch, Presider}

T2.1 DISPERSIVE FOURIER TRANSFORM SPECTROSCOPY OF SMALL SOLID SAMPLES - S.K. Kang, T. Dumelow and T.J. Parker, Royal Holloway and Bedford New College, U of London, Egham, Surrey TW20 OEX, UK

T2.2 A 30-300 GHz BROAD BAND DISPERSIVE FOURIER TRANSFORM SPECTROMETER FOR THE DIRECT MEASUREMENT OF DIELECTRIC PERMITTIVITY AND MAGNETIC PERMEABILITY - Hua Chi and Mohammed N. Afsar, Dept of Elec Engr, Tufts Univ, Medford, MA 02155

T2.3 A FABRY-PÉROT RESONATOR SYSTEM FOR MM-WAVE DIELECTRIC MEASUREMENTS AT CRYOGENIC TEMPERATURES - R. Heidinger, Inst für Material; F. Königer, Technologie-Transfer Labor, Karlsruhe, FRG; G. Link, Inst für Material

T2.4 A PRECISION $60 \mathrm{GHz}$ FABRY PEROT OPEN RESONATOR SYSTEM FOR COMPLEX DIELECTRIC MEASUREMENT - X. Li and Mohammed N. Afsar, Dept of Elec Engr, Tufts Univ, Medford, MA 02155

T2.5 CHECKING THE SURFACE RESISTANCE OF ORDINARY EMI-SHIELDING FOIL AT MMW FREQUENCIES USING A SIMPLE QUASI-OPTICAL TECHNIQUE - U.B. Unrau, Braunschweig Tech Univ, P.O. Box 3329, D-3300, FRG

T2.6 WAVEFRONT DIVIDING INTERFEROMETERS FOR SPATIAL COHERENT AND INCOHERENT RADIATION - K.D. Moeller, Fairleigh Dickinson U, Teaneck NJ 07666

T2.7 NEW METHOD FOR CALCULATION OF IR EFFECTIVE COMPLEX REFRACTIVE INDICES OF COMPOSITES - M. Zhang, N. Luo, W. Xu, and S.C. Shen, The Academy of Sciences of China, Shanghai, PRC

T2.8 A MILLIMETRE WAVE, SINGLE MODE, QUASI-OPTICAL, COMPLEX REFLECTOMETER OPERATING AS A NULLING BRIDGE - Andy Harvey and J.C.G. Lesurf, Univ of St. Andrews, North Haugh, St. Andrews, Fife, KY16 9SS, Scotland

T2.9 INFRARED RADIATION MEASUREMENT FOR MATERIALS WITH LOW EMISSIVITY - J. Su, S. Chen, M. Chen, Z. Zhang, Shanghai Inst of Technical Physics, Academia Sinica, Shanghai, 200083, China 
SESSION T3

Tuesday AM

MMW GUIDES I

Dec. 11

W. Kasparek, Presider

T3.1 GENERATION OF ROTATING HIGH-ORDER TE $\mathrm{T}_{m, n}$ MODES FOR COLD-TEST MEASUREMENTS ON HIGH-POWER QUASI-OPTICAL GYROTRON OUTPUT MODE CONVERTERS - M. Thumm, A. Jacobs, J. Pretterebner, Inst für Plasmaforschung, Univ Stuttgart, Pfaffenwaldring 31, D-7000 Stuttgart 80, FRG

T3.2 DESIGN AND COLD-TEST OF IMPROVED QUASI-OPTICAL HIGH-POWER MODE CONVERTERS FOR ROTATING HIGH-ORDER TE MODES - W. Kasparek, G.A. Müller, J. Pretterebner, M. Thumm, Inst für Plasmaforschung, Univ. Stuttgart, FRG

T3.3 A DEVICE TO MEASURE THE AMOUNT OF POWER IN THE CO- AND COUNTER ROTATING MODE - A. Möbius, Inst für Technische Physik, P.O. Box 3640, 7500 Karlsruhe, FRG; O. Dumbrajs, Tech Univ Hamburg-Harburg, Arbeitsbereich Hochfrequenztechnik

T3.4 EXPERIMENTAL STUDY OF A QUASI-OPTICAL MODE CONVERTOR FOR WHISPERING GALLERY MODE GYROTRONS - A. Li, M. Blank, J.A. Casey, K. Kreischer and R. Temkin, MIT Plasma Fusion Center, Cambridge, MA 02139

T3.5 A COAXIAL CONVERTER FOR TRANSFORMING A WHISPERING GALLERY MODE TO THE HE 11 MODE - C.P. Moeller and J.L. Doane, General Atomics, San Diego, CA 92186

T3.6 EQUIVALENCE PRINCIPLE AND PHYSICAL OPTICS MODELING OF RADIATION FROM TE ${ }_{0 n}$ AND TM Tn $_{0}$ MODE VLASOV LAUNCHERS - P.J. Sealy and R.J. Vernon, Dept Elec Engr, U of Wisconsin, Madison, WI 53706

T3.7 A SPECIAL QUASI-OPTICAL HIGH POWER COMBINING SYSTEM - Xie Weikai, Liu Shenggang, U of Electron Science \& Tech of China 


\section{R. Barker, Presider}

T4.1 COMPARISON OF EFFICIENCY AND BANDWIDTH OF SLOW AND FAST WAVE AMPLIFIERS - (Invited) - H.P. Freund, Science Appl Intl Corp, McLean, VA

T4.2 NONLINEAR THEORY OF RELATIVISTIC BACKWARD WAVE OSCILLATOR - B. Levush and T.M. Antonsen, Jr., Lab for Plasma Res, U of MD, College Pk, MD 20742

T4.3 SELF-CONSISTENT NONLINEAR ANALYSIS OF THE OROTRON - S. Lütgert, Tech Univ Hamburg-Harburg, Postfach 9010 52, D-2100 Hamburg 90, W.Germany

T4.4 EXPERIMENTS IN DIELECTRIC CERENKOV AND PERIODIC GRATING FREE ELECTRON MASERS FOR MILLIMETER WAVES - J.H. Bookse, J.E. Scharer, J. Joe, S.F. Chang and B. Meng, U of Wisconsin, 1425 Johnson Dr, Madison, WI 53706

T4.5 ANALYSIS OF DIELECTRIC CERENKOV AND PERIODIC GRATING FREE ELECTRON MASER AMPLIFIERS FOR MILLIMETER WAVES - S.F. Chang, J. Joe, J.E. Scharer and J. Booske, U of Wisconsin, 1425 Johnson Dr, Madison, WI 53706

T4.6 ENERGY EVALUATION OF SPONTANEOUS EMISSION WITH MANY HARMONICS DUE TO SPIRALING ELECTRONS IN A UNIFORM MAGNETIC FIELD FREEELECTRON LASER - Josip Soln, Harry Diamond Labs, Adelphi, MD 20783

T4.7 DIAGNOSTIC TECHNIQUES OF SINGLE PULSE MILLIMETER WAVES IN THE FREE ELECTRON LASER - Y. Chen, S. Fu, K. Hu, Y. Yan, Inst of Applied Electron, P.O. Box 527, Chengdu, Sichuan, PRC

T4.8 EFFECT OF THE SPACE-CHARGE WAVES ON THE GAIN OF FREE ELECTRON LASER WITH AN AXIAL GUIDE FIELD - S.C. Zhang, Dept Physics, U of Electron Science and Tech of China, P.O. Box 83, Chengdu, Sichuan 610054, PRC 


\section{Seashore, Presider}

T5.1 AN INTERCOMPARISON BETWEEN FREE SPACE AND IN-WAVEGUIDE POWER MEASUREMENT STANDARDS AT $94 \mathrm{GHz}$ - D.G. Moss, J.R. Birch, Division of Electrical Science, National Physical Laboratory, Teddington, Middlesex TW11 OLW, UK; D.A. Adamson, B. Lunt, T. Hodgetts, A. Wallace, National RF and Microwaves Standards Division, Royal Signals and Radar Establishment, Malvern, UK

T5.2 HIGH RELIABILITY SPUTTERED SCHOTTKY DIODES ON GaAs - Quang-Phong Pham, W.M. Kelly, P. Maaskant and J. O'Brien, National Microelectronics Research Centre, University College, Lee Maltings, Prospect Row, Cork, Ireland

T5.3 PERFORMANCE OF SIS MIXERS AT $205 \mathrm{GHz}$ EMPLOYING SUBMICRON Nb AND NbN TUNNEL JUNCTIONS - H.H.S. Javadi, W.R. McGrath, S.R. Cypher, B. Bumble, B.D. Hunt and H.G. LeDuc, Jet Propulsion Lab, California Inst Tech, Pasadena, CA 91109

T5.4 HIGH MOBILITY HOT ELECTRON MIXERS FOR MILLIMETER WAVES AND SUBMILLIMETER WAVES - J.X. Yang, W. Grammer, F. Agahi, K.M. Lau and K.S. Yngvesson, Dept of Electrical Engineering, U of MA, Amherst, MA 01003

T5.5 S PARAMETER MEASUREMENTS OF QUANTUM-WELL DEVICES - Olga Borić ${ }^{1}$, Timo J. Tolmunen ${ }^{2}$, Margaret A. Frerking ${ }^{2}$, Jonathan B. Hacker ${ }^{1}$, David B. Rutledge ${ }^{1}-$ ${ }^{1}$ Department of Electrical Engineering, CA Inst. Tech., Pasadena, CA 91125; ${ }^{2}$ Center for Space Microelectronics Technology, Jet Propulsion Laboratory, CA Inst. Tech., Pasadena, CA 91109

T5.6 RESONANT TUNNELING DIODE VIDEO DETECTORS FOR 10-100 GHz APPLICATIONS - I. Mehdi, J. East and G.I. Haddad, Center for High Frequency Microelectronics, The U of Michigan, Ann Arbor, MI 48109

T5.7 HARMONIC MIXING IN THIN FILM NIOBIUM NITRIDE JOSEPHSON TUNNEL JUNCTIONS - M.C. Wicks and P.R. Haycocks, Division of Electrical Science, National Physical Laboratory, Teddington, Middlesex TW11 OLW, UK

T5.8 MILLIMETER WAVE HARMONIC MIXER - Nathaniel King, M/A-COM Inc., Radar Products Division, Burlington, MA 01803 
T5.9 UNIPLANAR INTEGRATED KA-BAND MIXER - W. Grammer, J.X. Yang and K.S. Yngvesson, Dept of Electrical Engineering, U of MA, Amherst, MA 01003

T5.10 THE DESIGN AND PERFORMANCE OF A 75-110 GHz WIDEBAND SIS MIXER - D. Winkler, Physics Dept, Chalmers U. Tech, Gothenburg, Sweden; N.G. Ugras, A.H. Worsham, D.E. Prober, Applied Physics, Yale Univ; N.R. Erickson, P.F. Goldsmith, FCRAO Univ of Massachusetts

T5.11 QUASI-OPTICAL MILLIMETER WAVE BANDPASS FILTERS USING HIGH $\mathrm{T}_{c}$ SUPERCONDUCTORS AND THEIR OPTICAL RESPONSE - D. Zhang, D.V. Plant, M. Matloubian, T.W. Kim and H.R. Fetterman, Dept of EE, UCLA, Los Angeles, CA; K. Chou, S. Prakash, C. Deshpandey and R. Bunshah, Dept Materials Science and Engr, UCLA, Los Angeles, CA; K. Daly, TRW Inc. Redondo Beach, CA

T5.12 VIDEO DETECTION OF A 3 mm RADIATION BY InSb FIR DETECTOR - Xu Jianren, Gong Yaqian, Liu Songhe, Shanghai Institute of Technical Physics, Academia Sinica, Shanghai, PRC 
T6.1 COMPLEX REFRACTIVE INDICES OF SILICON CRYSTALS WITH VARIOUS CARRIER CONCENTRATIONS IN THE MILLIMETER AND SUBMILLIMETER WAVE REGIONS - M. Hangyo, N. Hasegawa, T. Matsuzawa, S. Sonoda, T. Hattori, K. Sakai, S. Nakashima, Dept of Applied Physics, Osaka Univ, Suita, Osaka 565, Japan

T6.2 FREQUENCY AND TEMPERATURE DEPENDENCE OF THE MM-WAVE DIELECTRIC PROPERTIES OF SILICON WITH HIGH d.c. RESISTIVITY - R. Heidinger, A. Kumlin, Inst für Material, Karlsruhe, FRG

T6.3 Ge FILMS FABRICATED BY PLASMA-ASSISTED DEPOSITION IN HYDROGEN PLASMA - N. Inoue, H. Kobayashi, Y. Yasuoka, Dept of EE, The Natl Defense Academy, 1-10-20 Hashirimizu, Yokosuka, 239 Japan

T6.4 INVESTIGATION OF TECHNIQUES FOR MINIMIZING RESISTIVITY OF THIN METALLIC FILMS AT SUBMILLIMETER WAVELENGTHS - K.S. Schieuer, J.M. Baird, L.R. Barnett and R.W. Grow, Univ of Utah, Salt Lake City, UT 84112

T6.5 EXPERIMENTAL STUDY OF THE ABSORPTION OF HIGH POWER $60 \mathrm{GHz}$ GYROTRON RADIATION IN A FUSED SILICA WINDOW - G.A. Whitehurst and A.N. Dellis, AEA Tech, Culham Lab, Abingdon, Oxon OX14 3DB, UK

T6.6 FTIR SPECTROSCOPY OF CVD AND NATURAL DIAMOND - A.J. Gatesman, R.H. Giles*, J. Waldman, Univ of Lowell, Lowell, MA 01854, *Univ of Lowell Research Foundation, Lowell, MA; L.P. Bourget, R. Post, ASTeX, Applied Science and Technology, Inc., Woburn, MA 01801

T6.7 SUBMILLIMETER EPR OF Co:Rb $\mathrm{MgF}_{4}$ AND ANOMALOUS G-VALUES - M. Motokawa, H. Ohta and N. Maki, Dept of Physics, Kobe Univ, Rokkodai, Nada,Kobe 657, Japan

T6.8 DESIGN AND FABRICATION OF NARROW BAND RADAR ABSORBING MATERIALS AT TERAHERTZ FREQUENCIES - R.H. Giles, A.J. Gatesman*, A.P. Ferdinand and J. Waldman*, University of Lowell Research Foundation; *University of Lowell, Lowell, MA 01854

T6.9 A CHARACTERIZATION OF ALBITE-ANORTHITE MIXTURES MELTED USING MICROWAVE RATIATION - C.W. Kim and T.T. Meek, The Univ of Tennessee at Knoxville 


\section{R.J. Vernon, Presider}

T7.1 DESIGN OF IMPROVED BRAGG REFLECTORS FOR RESONATORS IN OVERMODED HIGH-POWER MICROWAVE OSCILLATORS - (Invited) - J. Pretterebner and M. Thumm, Inst für Plasmaforschung, U Stuttgart, Pfaffenwaldring 31, D-7000 Stuttgart 80, FRG

T7.2 QUASI-OPTICAL CONVERSION OF THE OUTPUT FROM A WHISPERING-GALLERYMODE GYROTRON TO A FREE-SPACE BEAM WITH ARBITRARY POWER AND PHASE DISTRIBUTIONS ACROSS BOTH TRANSVERSE DIMENSIONS OF THE BEAM - J.A. Lorbeck and R.J. Vernon, U of Wisconsin, Madison, WI 53706

T7.3 QUASI-OPTICAL COMPONENTS AT THE GYROTRON/W.G. AND W.G./PLASMA INTERFACES IN A SYSTEM FOR ECRH AT $140 \mathrm{GHz}$ - A. Bruschi, S. Cirant, S. Nowak, G. Solari, Inst di Fisica del Plasma - EURATON/ENEA/CNR Assn., Milano, Italy; L. Mania, Dept Electron., Univ di Trieste, Trieste, Italy

T7.4 MATERIALS AND MACHINING PROCESSES FOR $140 \mathrm{GHz}$ GYROTRON RESONATORS - T. Geist*, G. Dammertz**, G. Hochschild**, W. Wiesbeck*, ${ }^{*}$ Univ Karlsruhe, Inst für Hochfrequenztechnik u El, Kaiserstr. 12, D-7500 Karlsruhe, W. Germany; ** Inst für Techn. Physik, P.O. Box 3640, D-7500 Karlsruhe, W. Germany

T7.5 FREQUENCY AGILE, QUASI-OPTICAL MODE CONVERTER FOR GYROTRONS - P.R. Winning, S.N. Spark and A.D.R. Phelps, Dept Physics \& Appl Physics, U of Strathclyde, Glasgow, G4 ONG, Scotland

T7.6 BI-DIRECTIONAL COUPLERS FOR HIGHLY OVERSIZED HE 11 WAVEGUIDES AND TEM $_{00}$ BEAM WAVEGUIDES - W. Kasparek and Klaus W. Kopp, Inst für Plasmaforschung, Univ Stuttgart, Pfaffenwaldring 31, D-7000 Stuttgart 80, FRG

T7.7 THE CYLINDRICAL WAVEGUIDE WITH SINUSOIDALLY-PERTURBED WALLS FOR HIGH-POWER GYROTRON APPLICATIONS - K.J. Bunch and R.W. Grow, Dept Elec Engr, U of Utah, Salt Lake City, UT 84112

T7.8 BRAGG REFLECTORS: SINUSOIDAL VERSUS RECTANGULAR CORRUGATION - C.K. Chong, D.B. McDermott, M.M. Razeghi and N.C. Luhmann, Jr., UCLA; M. Thumm and J. Pretterebner, U of Stuttgart, FRG 
T8.1 RECENT LONG-PULSE AND HIGH-AVERAGE-POWER TESTS ON A $140 \mathrm{GHz}$ GYROTRON - K. Felch, C. Hess, H. Huey, E. Jongewaard, H. Jory, J. Neilson, R. Pendleton and M. Tsirulnikov, Varian Assoc, Inc, 611 Hansen Way, Palo Alto, CA 94303

T8.2 A HIGH-POWER $120 \mathrm{GHz}$ WHISPERING-GALLERY-MODE GYROTRON WITH A BUILT-IN QUASI-OPTICAL MODE CONVERTER - (Invited) - Y. Mitsunaka, T. Kariya*, A. Yano*, Y. Okazaki*, T. Okamoto*, M. Komuro, Y. Hirata, K. Hayashi, Y. Itoh, T. Sugawara, Toshiba Corp, 4-1 Ukishimacho, Kawasaki-ku 210 Japan; K. Sakamoto and T. Nagashima, Naka Fusion Res Est, Japan Atomic Energy Res Inst, Naka, Ibaraki 311-01, Japan; * Toshiba Corp, Shimoishigami, Ohtawara, Tochigi 329-26, Japan

T8.3 500 kW QUASI-OPTICAL GYROTRON FOR 92 AND $185 \mathrm{GHz}$ - B. Jödicke, G. Agosti, H.-G. Mathews, ABB Infocom AG, CH-5401 Baden, Switzerland; M.Q. Tran, T.M. Tran, J.P. Hogge, H. Cao, S. Alberti, B. Isaak, P. Puggli, T. Goodman, CRPP, Switzerland; Natl Inst of Fusion Science Gyrotron Team, Nagoya, Japan: M. Mutho, M. Sato, M. Hosokawa, S. Kubo, K. Ohkubo

T8.4 EFFICIENT OPERATION OF A MEGAWATT GYROTRON - K.Y. Xu, T.L. Grimm, W.C. Guss, K.E. Kreischer and R.J. Temkin, MIT Plasma Fusion Center, Cambridge, MA

T8.5 DESIGN OF A $1 \mathrm{MW}, 280 \mathrm{GHz}$ GYROTRON OSCILlATOR - T.L. Grimm, K.E. Kreischer and R.J. Temkin, MIT Plasma Fusion Center, Cambridge, MA 02139

T8.6 DEPRESSED COLLECTOR PERFORMANCE ON THE NRL QUASIOPTICAL GYROTRON - T.A. Hargreaves, A.W. Fliflet, R.P. Fischer and M.L. Barsanti*, NRL, Washington, DC 20375; *JAYCOR, Inc, Vienna, VA 22182

T8.7 AN ENERGY RECOVERY SYSTEM FOR A QUASI-OPTICAL GYROTRON - A. Singh, V.L. Granatstein, G. Hazel, T. Hargreaves*, G. Saraph and J.M. Cooperstein, Lab for Plasma Res, U of MD, College Pk, MD 20742; *NRL, Washington, DC

T8.8 DEPRESSED COLLECTORS FOR MEGAWATT GYROTRONS - Michael E. Read and Alan J. Dudas, Physical Sciences Inc, 635 Slaters Lane, Suite G101, Alexandria, VA 22314 
SESSION W1

Wednesday AM

GUIDED PROPAGATION I

Dec. 12

T. Itoh, Presider

W1.1 CAD FOR ANALYSIS AND SYNTHESIS OF MM-WAVE TRANSMISSION LINES Adel M. S. de Oliveira, Humberto Abdalla Jr., Luis Afonso Bermudez, Universidade de Brasilia, Departamento de Engeharia Elétrica, Caixa Postal 153041, 70910 - Brasilia - DF - Brasil

W1.2 EXPLICIT FORMULAS OF PROPAGATION CHARACTERISTICS FOR UNILATERAL FINLINE - He Liquan, Wang Chunrong, Liu Chuanbin, Department of Radio Engineering, Southeast University, 210018, Nanjing, China

W1.3 MICROSTRIPLINE ON A SPHERICAL SUBSTRATE ALONG ONE OF ITS PARALLEL CIRCLE - Carlos Menezes Diniz Jr. and Attilio José Giarola, School of Electrical Engineering, State University of Campinas (UNICAMP), 13081 Campinas, SP, Brazil

W1.4 ADJUSTABLE RF TUNING ELEMENTS FOR PLANAR MILLIMETER WAVE AND SUBMILLIMETER WAVE CIRCUITS - W.R. McGrath, Center for Space Microelectronics Technology, Jet Propulsion Laboratory, California I of Technology, Pasadena, CA 91109; V. Lubecke and D.B. Rutledge, Department of Electrical Engineering, California I of Technology, Pasadena, CA 91125

W1.5 RADIATION CHARACTERISTICS OF A LEAKY NRD WAVE ANTENNA WITH TUNING APERTURE - Aosheng Rong and Sifan Li, Department of Radio Engineering, Southeast University, Nanjing 210018, Jiangsu, P.R.China

W1.6 STRONG COUPLINGS IN DIELECTRIC GRATING WAVEGUIDES - S.T. Peng, S.L. Wang and Z.M. Lu, New York I of Technology, Old Westbury, NY 11568; Howard Jenkinson, U.S. Army Armament Research, Development \& Engineering Center, Picatinny, NJ 07806-5000

W1.7 RADIATION LOSS REDUCTION IN BENT RECTANGULAR DIELECTRIC WAVEGUIDES WITH THREE DIELECTRIC LAYERS - Regina M. De F. Souza, School of Engineering of Joinville, U for the Development of the State of Santa Catarina (UDESC), 89.200 - Joinville, SP, Brazil; Attilio J. Giarola, School of Electrical Engineering, State University of Campinas (UNICAMP), C.P. 6101, 13081 - Campinas, SP, Brazil 
W1.8 NETWORK ANALYSIS OF EIGENVALUE PROBLEM FOR RADIALLY INHOMOGENEOUS CIRCULAR DIELECTRIC WAVEGUIDES - Shanjia Xu and Zhewang Ma, Department of Radio and Electronics, $U$ of Science and Technology of China, Hefei, Anhui, 230026, P.R. China

W1.9 COUPLED TRANSVERSE-T DIELECTRIC WAVEGUIDE - R.P. Singh and A.K. Tiwari, Department of Electronics, Maulana Azad College of Technology, (A Regional Engineering College), Bhopal, India

W1.10 NUMERICAL SOLUTION OF NONLINEAR TE WAVES IN MULTILAYER DIELECTRIC STRUCTURES - A.C.P. Zabeu and J.R. Souza, Center for Telecommunication Studies (CETUC), Pontifical Catholic U of Rio de Janeiro, Rua Marques de Sao Vicente, 225, 22453 Rio de Janeiro - RJ - Brazil

W1.11 APPLICATION OF THE EQUIVALENCE PRINCIPLE TO THE ANALYSIS OF DIELECTRICLOADED CAVITIES COUPLED TO WAVEGUIDES - A. Jöstingmeier and A.S. Omar, Technische Universität Hamburg-Harburg, Arbeitsbereich Hochfrequenztechnik, Postfach 9014 03, D-2100 Hamburg 90, West Germany 


\section{T.J. Parker, Presider}

W2.1 IR AND FIR MAGNETOSPECTROSCOPY IN HIGH FIELDS - (Invited Keynote) Michael von Ortenberg, Inst für Halbleiterphysik und Optik and Hochmagnet., Technische Univ Braunschweig, D-3300, Postfach 3329, FRG

W2.2 APPLICATION OF IR-MAGNETO OPTICS AND OPTICS FOR THE DETERMINATION OF DOPING PROFILES IN SEMICONDUCTORS - (Invited) - R. Nies, Technische Univ Braunschweig, FRG

W2.3 MAGNETOSPECTROSCOPY OF Cr DOPED PbTe - W. Lu, M. von Ortenberg, Tech Universität, Mendelssohnstraße Braunschweig, FRG

W2.4 FAR INFRARED PHOTO-HALL EXPERIMENTS ON SHALLOW DONOR TRANSITIONS IN n-GaAs - J. Burghoorn, A. van Klarenbosch, T.O. Klaassen, W.Th. Wenckebach, Huygens Lab, Univ of Leiden, P.O. Box 9504, NL-2300 RA, Leiden, The Netherlands; C.T. Foxon, Philips Res Labs, Redhill, Surrey UK

W2.5 SATURATION OF PHOTOIONIZATION OF SHALLOW ACCEPTORS IN p-Ge - G. Jungwirt, R. Kropf, and W. Prettl, Univ of Regensburg, W.Germany

W2.6 MCS: MICRO-CHANNEL ELECTRON SOURCE - K.A. Boulais, J.Y. Choe, and S.T. Chun, Naval Surface Warfare Center, Silver Spring, MD 20903

W2.7 INVESTIGATION ON CRYSTAL DEFECTS IN SEMICONDUCTORS THROUGH INFRARED AND MILLIMETER WAVES - T. Ohyama, Dept of Physics, College of General Education, Osaka Univ, Toyonaka, Osaka 560, Japan

W2.8 FIR STUDY OF TEA(TCNO $)_{2}-$ P. Janssen and A. Mordijck, Lab for Low Temp. and High Magnetic Fields, Celestijinenlaan 200D, B-3030 Leuven, Belgium

W2.9 HIGH MAGNETIC FIELD SPECTROSCOPY ON Hg(Fe)Se - Oliver Portugall ${ }^{1}$, H. Yokli $^{2}$, S. Takeyama ${ }^{2}$, I. Laue ${ }^{1}$, M. VonOrtenberg ${ }^{1}$, N. Miura ${ }^{2}$, W. Dobrowolski ${ }^{3},{ }^{1}$ Tech. Univ. Braunschweig, FRG; ${ }^{2}$ Inst Solid State Physics, Univ of Tokyo; ${ }^{3}$ Inst Physics, Polish Academy of Science, Warsaw 


\section{A. Hadni, Presider}

W3.1 ABSOLUTE POWER MEASUREMENTS OF FAR-INFRARED LASER LINES FROM SEVERAL DifFEREnT MOLECUlES - G. Carelli, A. Moretti, F. Strumia, Dipart. di Fisica, Univ di Pisa and C.N.R. Pisa; I. Gianinoni C.I.S.E., Milano

W3.2 DEVELOPMENT OF FIR POWER METER - S. Okajima, K. Kawahate*, H. Mori, S. Yasui and J. Fujita*, Appl Phys Lab, Chubu Univ, Kasugai, Aichi 487, Japan; * Natl Inst Fusion Sci, Nagoya, 464-01, Japan

W3.3 A PLANAR SCHOTTKY DIODE FOR SUBMILLIMETER WAVELENGTHS - W.L. Bishop, R.J. Mattauch and Thomas W. Crowe, Louis Poli* Semiconductor Device Lab, Dept of Elec Engr, U of Virginia, Charlottesville, VA 22903; *US Army, Ft. Monmouth, NJ 07703

W3.4 CHARACTERISTICS OF THE AVALANCHE BREAKDOWN FAR INFRARED PHOTODETECTOR - Fielding Brown and Robert P. Hoyt, Physics Dept, Williams College, Williamstown, MA 02167

W3.5 LOW GROWTH TEMPERATURE GaAs MICROBOLOMETER - J.M. Lewis, S.M. Wentworth and D.P. Neikirk, Dept of Elec and Comptr Engr, The Univ of Texas at Austin, Austin, TX 78712

W3.6 INTEGRATION OF AN ANTI-PARALLEL PAIR OF SCHOTTKY BARRIER DIODES - P.H. Ostdiek and Thomas W. Crowe, Dept of Elec Engr, U of Virginia, Charlottesville, VA 22903; I. Galin, Aerojet ElectroSystems Co., Azusa, CA 91702

W3.7 SUBMICRO THIN-FILM MOM-DIODES FOR THE DETECTION OF $10 \mu \mathrm{m}$ INFRARED LASER RADIATION - I. Wilke, D. Moix, W. Herrmann, F.K. Kneubühl, Infrared Physics Lab ETH, CH-8093 Zurich, Switzerland

W3.8 PERFORMANCE OF GaAs SCHOTTKY BARRIER DIODES AS MIXER IN THE THz RANGE - R.U. Titz, H.P. Röser, G.W. Schwaab, Max-Planck-Institut für Radioastronomie, Auf dem Hügel 69, D-5300 Bonn 1, West Germany 


\section{K. Felch, Presider}

W4.1 REVIEW OF GYROTRON DEVELOPMENT AT THE CENTRE DE RECHERCHES EN PHYSIQUE DES PLASMAS - (Invited) - CRPP-EPFL/ABB Gyrotron Development Group, presented by M.Q. Tran, CRPP, 21 Av. des Bains, CH-1007 Lausanne, Switzerland

W4.2 VELOCITY RATIO MEASUREMENT USING THE FREQUENCY OF BACKWARD WAVE OSCILLATIONS - P. Muggli, M.Q. Tran and T.M. Tran, CRPP, Ecole Polytechnique Fédéral de Lausanne, 21, Av. des Bains, CH-1007 Lausanne, Switzerland

W4.3 BEAM DIAGNOSTIC MEASUREMENTS IN A $140 \mathrm{GHz}$ MEGAWATT GYROTRON W.C. Guss, T.L. Grimm, K.E. Kreischer and R.J. Temkin, MIT Plasma Fusion Center, Cambridge, MA 02139

W4.4 AN ELECTRON VELOCITY DISTRIBUTION MEASUREMENT FOR GYROTRONS BASED ON THOMSON SCATTERING - M.E. Read and J.A. McKay, Physical Sciences, Inc, Alexandria, VA 22314

W4.5 INFLUENCE OF THE MAGNETIC FIELD TAPERING ON GYROTRON OPERATION - O. Dumbrajs, Tech Univ Hamburg-Harburg, D-2100 Hamburg 90, W. Germany

W4.6 COMPETITION BETWEEN THE FUNDAMENTAL AND THE SECOND HARMONIC IN QUASI-OPTICAL GYROTRONS - T.M. Tran, F. Dufaux, S. Alberti, D. Monselesan, M. Pedrozzi and M.Q. Tran, CRPP, Ecole Polytechnique Fédérale de Lausanne, 21, Av. des Bains, CH-1007 Lausanne, Switzerland

W4.7 NEW DESIGNS FOR HIGH POWER, MULTI-CAVITY GYROKLYSTRON AMPLIFIERS - P.E. Latham, W. Lawson, C.D. Striffler, W. Main and V.L. Granatstein, U of MD

W4.8 HIGH HARMONIC SYNCHROTRON RESONANCE MASER - J.L. Hirshfield and G.S. Park, Omega-P, Inc., PO Box 2008, New Haven, CT 06520 


\section{S.T. Peng, Presider}

W5.1 ANALYSIS OF THE SUPERCONDUCTING TRANSMISSION LINE - K.-S. Kong, C.W. Kuo, T. Kitazawa and T. Itoh, Department of Electrical and Computer Engineering, The U of Texas at Austin, Austin, TX 78712

W5.2 DESIGN OF A SINGLE-PERIOD 8.6 GHz TM TM $_{0} \mathrm{TM}_{11}$ SERPENTINE MODE CONVERTER AND TM $\mathrm{TM}_{01}$ AND $\mathrm{TM}_{11}$ BENDS IN A MODERATELY OVERMODED CIRCULAR WAVEGUIDE - G.H. Luo, D.A. Casper and R.J. Vernon, The U of Wisconsin, Madison, WI 53706-1691

W5.3 SPECTRUM OF UNWANTED SPURIOUS MODES GENERATED BY FLAT AND PHASE CORRECTING HE11 AND TE01 MIRRORS IN HIGHLY-OVERSIZED ELBOW BENDS - D. Wagner, M. Thumm, W. Kasparek, Institut für Plasmaforschung, Universität Stuttgart, Pfaffenwaldring 31, D-7000 Stuttgart 80, Fed. Rep. of Germany

W5.4 DIRECT TE01-HE11 MODE CONVERTERS IN CORRUGATED CIRCULAR WAVEGUIDE WITH PERIODIC CURVATURE PERTURBATIONS - W. Henle, H. Kumirć, H. Li, M. Thumm, Institut für Plasmaforschung, Universität Stuttgart, Pfaffenwaldring 31, D-7000 Stuttgart 80, Fed. Rep. of Germany

W5.5 EFFECT OF FINITE METALLIZATION THICKNESS ON RADIATION CHARACTERISTICS OF A DIELECTRIC WAVEGUIDE LOADED WITH PERIODIC STRIPS - Aosheng Rong and Sifan Li, Department of Radio Engineering, Southeast University, Nanjing 210018, Jiangsu, P.R.China

W5.6 ANALYSIS OF THE CHARACTERISTICS OF PERIODIC METALLIC STRIPS LOADED NRD WAVEGUIDES BY USING THE METHOD OF LINES FOR MILLIMETER WAVE FILTER AND ANTENNA APPLICATION - Wei Hong and Wen-Xun Zhang, Department of Radio Engineering, Southeast University, Nanjing, 210018, P.R.China

W5.7 A NEW APPROACH FOR ANALYSIS OF DIELECTRIC PERIODIC STRUCTURES - Shanjia Xu and Liguo Sun, Department of Raido and Electronics, University of Science and Technology of China, Hefei, Anhui, 230026, P.R.China

W5.8 PROPAGATION PROPERTIES OF A CIRCULAR DIELECTRIC WAVEGUIDE WITH PERIODIC METALLIC STRIPS - Shanjia Xu and Xinzhang Wu, Department of Radio and Electronics, University of Science and Technology of China, Hefei, Anhui, 230026, P.R.China 
W5.9 GENERALIZED SPECTRAL DOMAIN ANALYSIS OF WAVEGUIDE DISCONTINUITIES - A.S. Omar and K. Schünemann, Technische Universität Hamburg-Harburg, Arbeitsbereich Hochfrequenztechnik, Postfach 9014 03, D-2100 Hamburg 90, West Germany

W5.10 SPECTRAL DOMAIN TECHNIQUE FOR THE ANALYSIS OF INDUCTIVE DISCONTINUITIES IN RECTANGULAR WAVEGUIDE - Y.Y Tsai and A.S. Omar, Technische Universität Hamburg-Harburg, Arbeitsbereich Hochfrequenztechnik, Postfach 9014 03, D-2100 Hamburg 90, West Germany 
SESSION W6

Wednesday PM

MATERIAL CHARACTERIZATION

Dec. 12

U. Strom, Presider

W6.1 STUDY ON IR SPECTRUM EMISSIVITIES OF COMPOSITES - M. Zhang, N. Luo, W. Xu and S.C. Shen, Natl Lab for Infrared Physics, The Academy of Sciences of China, PRC

W6.2 INFRARED SPECTROSCOPY FOR THE STUDY OF URINARY STONES - R. Agarwal, V.R. Singh, M.M. Pradhan and V. Singh, Natl Physical Laboratory, New Delhi-110012 India

W6.3 TEMPERATURE DEPENDENCE OF DIELECTRIC PROPERTIES OF ALUMINA AT $20 \mathrm{GHz}$ - J. Mollá, A. Ibarra, EURATOM/CIEMAT Assoc., Av. Complutense, 22, 28040 Madrid, Spain; A. Hernández, J.M. Zamarro, J. Margineda, Dept Fisica Aplicada, Univ Murcia, Campus Espinardo, Murcia, Spain

W6.4 THE DIELECTRIC PROPERTIES OF $\mathrm{CaF}_{2}$ AND LiF AT MM- AND SUBMM-WAVELENGTHS - J.R. Birch, Natl Physical Lab, Teddington, TW11 OLW, UK; R. Heidinger, Kernforschungszentrum, FRG; J. Birch, Div of Electrical Science, NPL, UK

W6.5 SUBMILLIMETER PHOTOACOUSTIC DETECTION OF SOME BIOLOGICAL SPECIMENS - J. Su${ }^{1}, \mathrm{~S}$. Xiong ${ }^{1}, \mathrm{M} . \mathrm{Qian}^{2}$ and D. $\mathrm{Wu}^{2}$, L. Ding ${ }^{1}{ }^{1}$ Shanghai Inst of Technical Physics, Academia Sinica, Shanghai, 200083, PRC; ${ }^{2}$ Acoustic Research Institute, Tongji University, Shanghai, 200092, PRC

W6.6 ANALYSIS OF HIGH POWER MICROWAVE WINDOWS - K.A. Connor, S.J. Salon, S. Kasibhotla and P.S. Shin, Rensselaer Polytechnic Inst., Troy, NY 12180; L.J. Hadwin, B.G. Ruth and L.F. Libelo, Harry Diamond Lab, Adelphi, MD

W6.7 COMPLEX PERMITTIVITIES OF IR WINDOW MATERIALS BETWEEN 18 AND 40 $\mathrm{GHz}$ - F.I. Shimabukuro, S.L. Johns and H.B. Dyson, The Aeorspace Corp., Los Angeles, CA 90009-2957 


\section{J.W. Dees, Presider}

W7.1 A HIGH ELECTRON MOBILITY VARACTOR DIODE - W.C.B. Peatman and Thomas W. Crowe, Dept of Elec Engr, U of Virginia, Charlottesville, VA 22903

W7.2 SECOND HARMONIC GENERATION WITH 30 ps OFID $10 \mu \mathrm{m} \mathrm{CO}_{2}$ LASER PULSES IN POLYCRYSTALLINE NONLINEAR MATERIALS - R. Kesselring, A.W. Kälin and F.K. Kneubühl, Infrared Physics Lab ETH, CH-8093 Zurich, Switzerland

W7.3 A DELTA-DOPED VARACTOR DIODE FOR SUBMILLIMETER WAVELENGTHS B.J. Rizzi, Thomas W. Crowe and W.C.B. Peatman, Dept of Elec Engr, U of VA, Charlottesville, VA

W7.4 THEORY OF THE STACKED WAVEGUIDE HIGHPASS FILTER AND THE BEVELED WAVEGUIDE SPECTROMETER FOR SUB-MILLIMETER WAVES - Igor Alexeff, Fred Dyer, Victor Porter, David Saffer and Mark Rader, The U of Tennessee, Elec and Cmptr Engr Dept, 206 Ferris Hall, Knoxville, TN 37996-2100

W7.5 MICROWAVE RESPONSE OF A COPLANAR WAVEGUIDE PHASE SHIFTER TO PULSED OPTICAL ILlimiNATION - M.S. Islam, P. Cheung, D.P. Neikirk and T. Itoh, Microelectronics Research Center, The U of Texas at Austin, ENS439, Austin, TX 78712

W7.6 HIGH ORDER HARMONIC MIXING FOR FIR LASER RECEIVING - Zhou Baoqing, Mi Zhengyu, Shanghai I of Tech Physics, Academia Sinica, 420 Zhong Shan Bei Yi Road, 200083, Shanghai, China

W7.7 IN LINE SBS BASED MULTI-CHANNEL NEAR IR FIBER-OPTIC DEVICES FOR AMPLIFICATION, SWITCHING AND CHANNEL SELECTION - C. Yu and Haishan Zhou, Dept of Elec Engr, North Carolina A\&T State Univ, Greensboro, NC 27411

W7.8 SUPERVISERING SYSTEM BY INFRARED/VISIBLE IMAGE - Kazumitsu Nukui, Tokyo Gas Co., Ltd., 1-7-7 Suehiro-cho, Tsurumi-ku Yokohama 230, Japan; T. Nakamura, Fujitsu Co., Ltd., Japan 


\section{H. Freund, Presider}

W8.1 $140 \mathrm{GHz}$ GYROTRON DEVELOPMENT AT KfK KARLSRUHE - (Invited) - E. Borie, G. Dammertz, O. Dumbrajs*, G. Gantenbein, T. Geist**, G. Hochschild, M. Kuntze, A. Möbius, H.-U. Nickel, B. Piosczyk, H. Wenzelburger, Inst. Technische Physik, P.O. Box 3640, 7500 Karlsruhe, FRG; * Tech Univ Hamburg-Harburg, Arbeitsbereich Hochfrequenztechnik; ** Univ Karlsruhe, Inst Hochstfrequenztechnik und Elektronik, Karlsruhe, FRG; Z. Liao, Inst. Electron., Academia Sinica, Beijing, China

W8.2 GYROTRON IVA - G.F. Brand, P.W. Fekete, K. Hong K.J. Moore, School of Physics, U of Sydney, NSW, 2006, Australia; T. Idehara, Dept of Appl Physics, Fukui Univ, Fukui 910, Japan

W8.3 COMPENSATION OF THE BEAM SPACE CHARGE AND CONSEQUENCES FOR THE DESIGN OF A GYROTRON - B. Piosczyk, Inst f Technische Physik, P.O. Box 3640, 7500 Karlsruhe 1, FRG

W8.4 INFLUENCE OF ECCENTRICITY OF THE ELECTRON BEAM IN A RESONATOR ON EFFICIENCY AND MODE COMPETITION IN GYROTRONS - G. Dammertz, O. Dumbrajs*, and G. Gantenbein, Inst f Technische, FRG; * Tech Univ Hamburg-Harburg, FRG

W8.5 A TWO-CAVITY QUASIOPTICAL GYROKLYSTRON - R.P. Fischer and W.M. Manheimer, NRL, Washington, DC 20375

W8.6 UPSCALED NSWC CUSTRON EXPERIMENT - Joon Y. Choe, Kevin Boulais, Marlene Skipec and S.T. Chun, Naval Surface Warfare Ctr, Silver Spring, MD 20903

W8.7 NONLINEAR SIMULATIONS OF HIGH POWER GYROTRON OPERATION - T.M. Antonsen Jr., S.-Y. Cai and B. Levush, Lab for Plasma Res, U of MD, College Pk, MD 20742

W8.8 REGIONS OF SINGLE MODE OPERATION IN HIGH POWER GYROTRON OSCILLATOR - G. Saraph, G.I. Lin, T.M. Antonsen, Jr., and B. Levush, U of MD, College Park, MD 20742

W8.9 NEGATIVE ENERGY CYCLOTRON RESONANCE MASER - E.E. Lednum*, D.B. McDermott, A.T. Lin and N.C. Luhmann, Jr., U of CA at Los Angeles, 405 Hilgard Ave, Los Angeles, CA 90024; *Air Force Weapons Lab, Kirkland AFB 
SESSION Th1

Thursday AM

INTEGRATED CIRCUITS

Dec. 13

\section{J.C. Wiltse, Presider}

Th1.1 STATE-OF-THE-ART REALIZATION OF MILLIMETER-WAVE SYSTEMS - A TECHNOLOGY SURVEY (Invited) - Holger H. Meinel, Deutsche Aerospace AG, Abt. UE/2, Leopolstrasse 175, D-8000 Muenchen 44

Th1.2 PROGRESS IN MILLIMETER WAVE MONOLITHIC TRANSCEIVERS (Invited) - C.R. Seashore, Honeywell Inc., Defense Systems Group, Minnetonka, MN 55343

Th1.3 RECENT DEVELOPMENTS OF MICROWAVE/MILLIMETER-WAVE INTEGRATED ACTIVE ANTENNA ELEMENTS - K. Chang, Department of Electrical Engineering, Texas A\&M University, College Station, TX 77843-3128

Th1.4 A MONOLITHIC $60 \mathrm{GHz}$ MULTISTAGE InGaAs HEMT LOW NOISE AMPLIFIER - Leonard Shaw, David Brunone, M. Sholley, W. Jones, D. Streit and P. Liu, TRW Inc., One Space Park, Redondo Beach, CA 90279

Th1.5 PROGRESS IN GRID OSCILLATORS - Z.B. Popović, Univ of Colorado, Boulder, CO; R.M. Weikle, II, M. Kim, D.B. Rutledge, California Inst Tech, Pasadena, CA

Th1.6 MEASURED PERFORMANCE AND STATISTICS OF A 21-GHz FOUR-BIT MONOLITHIC PHASE SHIFTER USING A COMMERCIAL FOUNDRY PROCESS - J.E. Wallace, M.H. Florian, G.A. Ellis, Boeing Aerospace and Electronics Company, High Technology Center, P.O. Box 3999, M/S 7J-65, Seattle, WA 98124

Th1.7 Ka-BAND POWER-COMBINING MMIC ARRAY - J. Chang, D.H. Schaubert, K.S. Yngvesson, Univ of Mass, Amherst, MA 01003; J. Huang, V. Jamnejad, D. Rascoe and A.L. Riley, Jet Propulsion Lab, Pasadena, CA 91109

Th1.8 DEVELOPMENT OF MONOLITHIC SOLID-STATE DIODE-GRID FREQUENCY MULTIPLIER ARRAYS - R.J. Hwu, X.H. Qin, W.S. Wu, L.B. Sjogren and N.C. Luhmann, Jr., Department of Electrical Engineering, U of California, Los Angeles, CA; D.B. Rutledge, California I of Technology; B. Hancock, U. Lieneweg, J. Maserjian, JPL 


\section{Thumm, Presider}

Th2.1 OUTPUT COUPLING OF A QUASI-OPTICAL FABRY-PEROT RESONATOR BY MEANS OF A DIFFRACTIVE GRATING IN THE MM WAVE RANGE - J.P. Hogge, H. Cao, W. Kasparek*, T.M. Tran, M.Q. Tran, CRPP, Ecole Polytechnique Fédérale de Lausanne, 21, Av. des Bains, CH-1007 Lausanne, Switzerland; * Inst für Plasmaforschung, Univ Stuttgart, Pfaffenwaldring 31, D-7000 Stuttgart 80, FRG

Th2.2 A MAGICTRAC DESIGN FOR MTX TRANSPORT SYSTEM - M.A. Makowski, TRW Inc, One Space Pk, Redondo Beach, CA 90278; B.W. Stallard, J.A. Byers, LLNL, Livermore, CA 94550

Th2.3 INVESTIGATION ON CRYOGENICALLY COOLED WINDOWS FOR MW/CW GYROTRONS - H.-U. Nickel, A. Hofmann, Kernforschungszentrum (KfK), P.O. Box 3640, D-7500 Karlsruhe, FRG; P. Norajitra, Inst für Material und Festkörperforschung III, FRG

Th2.4 WINDOW MATERIALS FOR HIGH POWER GYROTRONS - M.N. Afsar, H. Chi and X. Li, Elec Engr Dept, Tufts Univ, Medford, MA 02155

Th2.5 HIGH POWER $60 \mathrm{GHz}$ TRANSMISSION THROUGH A CYCLOTRON RESONANCE REGION IN A LOW PRESSURE WAVEGUIDE - A.N. Dellis and G.A. Whitehurst, AEA Tech, Culham Lab, Abingdon, Oxon OX14 3DB, UK

Th2.6 USE OF ORDINARY AND EXTRAORDINARY WAVES TO MEASURE ELECTRON DENSITIES ON THE TOKAMAK TORE SUPRA - P. Millot, F. Mourgues, M. Paume, Assoc Euratom-CEA, DRFC/SPPF CEN, F13108 Saint-Paul-Les-Durance, France

Th2.7 ECE DIAGNOSTICS ON THE FRASCATI TOKAMAK UPGRADE - P. Buratti, O. Tudisco, M. Zerbina, Assoc EURATOM-ENEA sulla Fusione, Centro Ricerche Energie Frascati, C.P. 65, 00044 Frascati, Rome, Italy

Th2.8 CALIBRATION OF FABRY-PEROT INTERFEROMETERS FOR ELECTRON CYCLOTRON EMISSION MEASUREMENTS ON THE TORE SUPRA TOKAMAK C. Javon and M. Talvard, Assoc Euratom-CEA, France

Th2.9 PHASE ANALYSIS FOR A 3-MM MICROWAVE INTERFEROMETER ON THE ALVAND IIC TOKAMAK - M. Avakian and M. Ghorannevis, Plasma Physics Group A.E.O.I., Dept Physics Islamic Azad Univ (North Branch) 


\section{SESSION Th3}

Thursday AM

LASERS I

Dec. 13

\section{Skatrud, Presider}

Th3.1 TUNABLE RAMAN AND PARAMETRIC PULSED OPTICALLY PUMPED FIR LASERS - (Invited Keynote) V.A. Batanov, A.O. Radkevich, A.L. Telyatnikov and A.Yu. Volkov, Inst of Physics and Tech of the USSR Academy of Sciences, 117218, Moscow, Krasikova $25 \mathrm{~A}, \mathrm{USSR}$

Th3.2 CORRELATION OF J-NUMBER, OPTIMUM PRESSURE AND SPECTRAL TYPE IN METHYL FLOURIDE RAMAN FIR LASERS - Jerald R. Izatt, Physics Dept, U of Alabama, Tuscaloosa, AL 35487

Th3.3 OPTICALLY PUMPED FIR PERTURBATION LASER - David D. Skatrud, Army Research Office, Research Triangle Park, NC 27709

Th3.4 THE METHANOL ABSORPTION SPECTRUM BETWEEN 350 AND $1250 \mathrm{~cm}^{-1}-$ G. Moruzzi, M. Pancioli and F. Strumia, Dept di Fisica dell'Università di Pisa, Piazza Torricelli 2, I-56126 Pisa; B.P. Winnewisser, Physikailisch-Chemisches Inst der JustusLiebig Univ, Heinrich-Buff-Ring 58, D-6300 Giessen, W. Germany

Th3.5 ULTRASHORT SUPERRADIANT $496 \mu \mathrm{m}-\mathrm{CH}_{3} \mathrm{~F}-\mathrm{LASER}$ EMISSIONS OPTICALLY PUMPED BY TRUNCATED HYBRID-10 $\mu \mathrm{m}-\mathrm{CO}_{2}-\mathrm{LASER}$ PULSES - D. Scherrer, A.W. Kälin, R. Kesselring and F.K. Kneubühl, Infrared Physics Lab ETH, CH-8093 Zurich, Switzerland

Th3.6 $\mathrm{CD}_{3}$ OD OPTICALLY PUMPED BY A WAVE GUIDE $\mathrm{CO}_{2}$ LASER: NEW FIR LASER LINES AND FREQUENCY MEASUREMENTS - E.M. Telles, J.C.S. Moraes, A. Scalabrin, D. Pereira, Inst de Fisica-Deq-B-Unicamp-Cx.P.6165, 13081 Campinas, SP Brasil; A. Moretti, G. Carelli, N. Ioli, A. Messina, F. Strumia, Dept di Fisica and Cnr, Piazza Toricolli 2, I-56100, Pisa Italy

Th3.7 ${ }^{13} \mathrm{CH}_{3} \mathrm{~F}$ AND ${ }^{12} \mathrm{CH}_{3} \mathrm{~F}$ MIXTURE FIR RAMAN LASER - V.A. Batanov, V.B. Fleurov, A.O. Radkevich, A.L. Telyatnikov and A.Yu. Volkov, Inst of Physics and Tech of the USSR Academy of Sciences, 117218, Moscow, Krasikova 25A, USSR

Th3.8 NEW FAR INFRARED LASER LINES FROM ${ }^{13} \mathrm{CH}_{2} \mathrm{~F}_{2}$ AND FREQUENCIES MEASUREMENTS - G. Carelli, N. Ioli, A.M. Messina, A. Moretti, F. Strumia, S. Zerbetto*, Physics Dept and CNR, Piazza Toricelli 2, I-56126 Pisa, Italy; ${ }^{*}$ Inst de Fisica, Brasil 
Th3.9 A TUNABLE FAR-INFRARED SPECTROMETER OPERATING IN THE $30 \mathrm{~cm}^{-1} \mathrm{RE}$ GION - S.R. Boardman, Univ of Cambridge, Dept of Chemistry, Lensfield Road, Cambridge CB2 1EP

Th3.10 SELF FOCUSSING OF PUMPING RADIATION IN HN 3 RAMAN LASER - V.A. Batanov, V.S. Petriv, A.O. Radkevich, A.L. Telyatnikov and A.Yu. Volkov, I of Physics and Tech of the USSR Academy of Sciences, 117218, Moscow, Krasikova 25A, USSR 
SESSION Th4

Thursday AM

GYROTRON IV

Dec. 13

M.Q. Tran, Presider

Th4.1 ISSUES FOR THE DEVELOPMENT AND THE DESIGN OF AN ELECTRON CYCLOTRON WAVE SYSTEM FOR ITER - (Invited) - L. Rebuffi, V. Parail, N. Fujisawa, H. Hopman, W. Lindquist, H. Kirmura, W. Nevins, M. Sironi, D. Swain, J-G. Wègrowe, ITER Team, Max-Planck-Institut für Plasmaphysik, D-8046 Garching, FRG

Th4.2 BROADBAND OPERATION OF A MILLIMETER-WAVE GYRO-TWT - G.S. Park and S.Y. Park, Omega P., Inc, New Haven, CT; R.K. Kyser, B.K. Systems, Inc, Rockville, MD; C.M. Armstrong and A.K. Ganguly, NRL, Code 6840, Washington, DC 20375

Th4.3 IMPROVED OPERATION OF A $140 \mathrm{GHz}$ GYROTRON BACKWARD-WAVE OSCILLATOR - M.A. Basten, W. C. Guss, K.E. Kreischer, R.J. Temkin, MIT Plasma Fusion Center; M. Caplan and B. Kulke, LLNL, Livermore, CA

Th4.4 AN IMROVED $94 \mathrm{GHz} \mathrm{TE}_{13}$ GYROTRON - M. Rhinewine, T.A. Hargreaves and M.L. Barsanti*, NRL, Washington, DC; *JAYCOR, Inc, Vienna, VA 22182

Th4.5 MAGNETIC COMPRESSION OF CUSP PRODUCED ELECTRON BEAM - S.T. Chun, Joon Y. Choe, Keven Boulais and Marlene Skopec, Naval Surface Warfare Ctr, Silver Spring MD 20903

Th4.6 THEORY OF A TWO-CAVITY GYROTRON FREQUENCY MULTIPLIER - A.H. McCurdy, U of So California, Los Angeles, CA 90089

Th4.7 NONLINEAR SELF-CONSISTENT ANALYSIS FOR A TWO-STAGE GYRO-TWT AMPLIFIER - C.S. Kou, D.B. McDermott, N.C. Luhmann, Jr., U of California, Los Angeles, CA

Th4.8 SIMULATED EFFICIENCY OF THE SLOW WAVE CYCLOTRON AMPLIFIER - S. Ahn and A.K. Ganguly, US Naval Res Lab, Washington, DC 20375

Th4.9 SELF CONSISTENT THEORY FOR GYROTRONS INCLUDING EFFECT OF VOLTAGE DEPRESSION - E. Borie, G. Gantenbein, Kernforschungszentrum Karlsruhe, ITP, Postfach 3640, 7500 Karlsruhe 1, FRG

Th4.10 DESIGN AND TESTS OF A THREE-CAVITY GYROKLYSTRON AMPLIFIER - W. Main, S. Tantawi, P.E. Latham, W. Lawson, J. Calame, D. Welsh, B. Hogan, J. Hamilton, H. Matthews, S. Demske, C.D. Striffler, M. Reiser and V.L. Granatstein, Lab of Plasma Res, U of MD, College Pk, MD 20742 
SESSION TH5

Thursday PM

MMW ANTENNAS

Dec. 13

\section{F. Schwering, Presider}

Th5.1 CONFORMAL MICROSTRIP ANTENNAS FOR MILLIMETER WAVE APPLICATIONS - A.R. Jha, Jha Technical Consulting Services, Cerritos, CA 90701

Th5.2 DIFFRACTION FIELD OF QUASI-OPTICAL RESONATOR CALCULATED BY COMPLEX RAY THEORY - Jun-xiang Ge, Si-fan Li and Yi-Yuan Chen, Southeast Univ, Nanjing, PRC

Th5.3 ACCURATE FULL-WAVE APPROACH FOR MODELING PATCH ANTENNAS - B.J. Rubin, IBM T.J. Watson Research Center, Yorktown Heights, NY 10598; R.A. York and R.C. Compton, School of Elec Engr, Cornell Univ, Ithaca, NY 14853

Th5.4 RECENT DEVELOPMENTS IN PHASE-CORRECTING FRESNEL ZONE PLATE ANTENNAS - J.C. Wiltse and J.E. Garrett, GTRI, GA Inst Tech, Atlanta, GA 30332

Th5.5 BREWSTER ANGLE EFFECT ON THE PERFORMANCE OF OMNI-DIRECTIONAL CIRCULAR DIELECTRIC GRATING ANTENNA - IMPROVED PERTURBATION ANALYSIS - Shanjia Xu and Zhewang Ma, Dept of Radio and Electronics, U of Science and Tech of China, Hefei, Anhui, 230026, P.R.China

Th5.6 94 GHz INTEGRATED-HORN ANTENNAS: IMPEDANCE, PATTERNS AND DOUBLEPOLARIZED APPLICATIONS - W. Ali-Ahmad, G. Eleftheriades and G.M. Rebeiz, NASA, EECS Dept-U of Michigan, Ann Arbor, MI 48109

Th5.7 MILLIMETER-WAVE DOUBLE-DIPOLE ANTENNAS FOR HIGH-EFFICIENCY REFLECTOR ILLUMINATION - D. Filipovic, W. Ali-Ahmad and G.M. Rebeiz, NSAS/Ctr for Space Terahertz Technology, EECS Dept--U of Michigan, Ann Arbor, MI 48109-2122

Th5.8 EXPERIMENTAL INVESTIGATION ON COPLANAR WAVEGUIDE ANTENNAS Xian Hua Yang and Wen Xun Zhang, Southeast Univ, Nanjing, PRC

Th5.9 SPECTRAL-DOMAIN ANALYSIS OF AN ELECTRONIC SCANNING MMW ANTENNA - T.H. Wu and K.S. Chen, Zhejiang Univ, Hangzhou, PRC 
Th5.10 PHASE AND PHASE CENTERS IN QUASI-OPTICAL SYSTEMS - D.H. Martin and R.J. Wylde, Dept Physics, Queen Mary and Westfield College, Mile End Rd, London E1 4NS

Th5.11 KA-BAND POWER-COMBINING MMIC ARRAY - J. Chang, D.H. Schaubert, K.S. Yngresson, Dept of Elec and Cmptr Engr, Univ of Mass., Amherst, MA 01003; J. Huang, V. Jamnejad, D. Rascoe and A.L. Riley, Jet Prop. Lab, California Inst of Tech, Pasadena, CA 91109 
Th6.1 3MM QUASI-OPTICAL HARMONIC POWER COMBINING TECHNIQUE - Chengtian Xue, Qiao-min Wang*, Hui-zhen Li and Li-ming Lei, Dept Electron Science, Nankai Univ, PRC; ${ }^{*}$ Cmptr Center, Tianjin Univ, PRC

Th6.2 ELECTRON PROPERTIES IN GaAs FOR THE DESIGN OF MM-WAVE IMPATTs Heribert Eisele, 2245 EECS Bldg, Univ of Michigan, Ann Arbor, MI 48109

Th6.3 Ka-BAND LARGE BANDWIDTH NOISE SIGNAL SOURCE - Y.A. Myasin, V.D. Kotov and Y.V. Andreyev, Inst Radioengr and Electron, Academy of Science of the USSR, 18, Marx Av, GSP-3, Moscow, USSR

Th6.4 A TWO--DIMENSIONAL PERTURBATION TECHNIQUE TO MODEL ION-IMPLATED GaAs MESFET FOR MILLIMETER-WAVE SYSTEMS - Eric Donkor and Faquir C. Jain, Elec and Systems Engr Dept, Univ of Connecticut, Storrs, CT 06269

Th6.5 SCATTERING OF PLANE WAVES BY MICROSTRIPLINES OF FINITE CONDUCTIVITY - S.T. Peng and Z.M. Lu, NY Inst of Tech, Old Westbury, NY 11568; R.T. Kinasewitz, US Army Armament Res, Devmt and Engr Ctr, Picatinny, NJ 07806-5000

Th6.6 A SPECTRAL DOMAIN METHOD FOR THE FULL WAVE ANALYSIS OF A MICROSTRIPSLOTLINE TRANSITION - Wolfgang Schwab and Wolfgang Menzel*, Universität Ulm, Abteilung Mikrowellentechnik, Liststrasse 3, D-7900 Ulm, FRG; *Univ of Ulm, Microwave Tech, P.O. Box 4066, D7900 Ulm, FRG

Th6.7 Millimeter WAVE METEOROLOGICAL RADARS - Stephen L. Johnston, International Radar Directory, 4015 Devon St, Huntsville, AL 35802

Th6.8 L-T SELECTION RULES FOR TRANSITIONS BETWEEN EXCITON (BIEXCITON) SUBBANDS IN DIRECT-GAP SEMICONDUCTORS - G.K. Vlasov, Space Res Inst, Moscow, USSR

Th6.9 SPHERICAL EXCITONS IN MANYELECTRON ATOMS (MOLECULES) AND THEIR INTERACTION WITH MULTIPOLE WAVES - G.K. Vlasov, Space Res Inst, Moscow, USSR

Th6.10 INVERSION AND LASING IN p-Ge - Yu L. Ivanov, Academy of Sciences of the USSR, Leningrad, USSR 


\section{J. Izatt, Presider}

Th7.1 RECENT DEVELOPMENTS AND APPLICATIONS OF PICOSECOND-PULSE $1-\mu \mathrm{m}$ $\mathrm{CO}_{2}$ LASERS - (Invited Keynote) F.K. Kneubühl, Infrared Physics Lab, ETH, CH-8093 Zurich, Switzerland

Th7.2 TRANSVERSE FEEDBACK ENHANCEMENT IN MINIATURE OPFIRL - Yikun Lin and Xizhang Luo, Dept of Radio-Electronics, Zhongshan Univ, Guangzhou, PRC

Th7.3 HIGH-PRESSURE $\mathrm{CO}_{2}$ LASER AMPLIFIER FOR 30 ps OFID AND 50 ns TEA $10 \mu \mathrm{m}$ $\mathrm{CO}_{2}$ LASER PULSES - R. Kesselring, A.W. Kälin and F.K. Kneubühl, Infrared Physics Lab ETH, CH-8093 Zurich, Switzerland

Th7.4 LASER INDUCED NARROWING AND SATURATION BROADENING EFFECTS IN OPFIRL - Yikun Lin and Xizhang Luo, Zhongshan Univ, PRC

Th7.5 NEW PLASMA SHUTTERS FOR PICOSECOND-PULSE OPTICAL-FREE-INDUCTIONDECAY $10 \mu \mathrm{m} \mathrm{CO}_{2}$ LASERS - A.W. Kälin, R. Kesselring, T.L. Kopiczynski, H.J. Schötzau and F.K. Kneubühl, Infrared Physics Lab ETH, Switzerland

Th7.6 HIGH FREQUENCY MODULATION OF THE LIGHT WAVE INCREMENT IN THE DOUBLE HETEROJUNCTION LAZER - V.B. Gorfinkel, B.M. Gorbovitskiy, I.I. Filatov

Th7.7 INFLUENCE OF FIR LASER EMISSION ON ENZYME ACTIVITY - V.A. Batanov, A.I. Demin, V.B. Fleurov, N.N. Tulyakov and A.Yu. Volkov, Inst of Physics and Tech of the USSR Academy of Sciences, 117218, Moscow, Krasikova 25A, USSR; M.Yu. Aksenov, V.M. Govorun, A.B. Kapitanov, V.E. Tretyakov, Inst of Physico-chemical Medicine, Ministry of Health, RSFSR, Priogovskya 1a, Moscow, USSR

Th7.8 OPTICAL FIBER LASERS MADE FROM RARE-EARTH-DOPED HEAVY-METAL FLOURIDE GLASSES EMITTING IN THE 2.5-3 $\mu$ m WAVELENGTH RANGE - L. Wetenkamp and U.B. Unrau, Technische Univ Braunschweig, Inst für Hochfrequenztechnik, D-3300 Braunschweig, West Germany

Th7.9 NOVEL OPTICALLY PUMPED FIR LASER WITH THIN GOLD-COATED WAVEGUIDE CAVITY - Su Jinwen, Xiong Shouren, L. Ding and Y. Wang, Natl Lab for IR Physics, Shanghai Inst of Technical Physics, Academia Sinica, Shanghai, 200083, China 
SESSION Th8

Thursday PM

GYROTRON V

Dec. 13

S.H. Gold, Presider

Th8.1 HIGH-POWER CARM EXPERIMENTS - (Invited) - B.G. Danly, MIT Plasma Fusion Center, Cambridge, MA 02139

Th8.2 HIGH POWER MICROWAVE GENERATION FROM A TWO-CAVITY GYROKLYSTRON EXPERIMENT - (Invited) - W. Lawson, J. Calame, D. Welsh, B. Hogan, W. Main, P.E. Latham, C.D. Striffler and V.L. Granatstein, Lab for Plasma Research, U of MD, College Park, MD 20742

Th8.3 THE NRL PLASMA-FILLED GYROTRON EXPERIMENT - S.H. Gold, C.A. Sullivan, A.C. Ting, A.W. Fliflet, W.M. Manheimer, Beam Physics Branch, Plasma Physics Div, NRL, Washington, DC 20375; D.A. Kirkpatrick, Science Appl Intl Corp, McLean, VA 22102; A.K. Kinkead, FM Technologies, Inc., Fairfax, VA 22032

Th8.4 THE NRL $85 \mathrm{GHz}$ CARM AMPLIFIER EXPERIMENT - C.A. Sullivan, R.B. McCowan and S.H. Gold, NRL, Washington, DC 20375

Th8.5 DESIGN OF THE NRL $280 \mathrm{GHz}$ IREC MASER EXPERIMENT - R.B. McCowan, T.A. Hargreaves and A.W. Fliflet, NRL, Washington, DC 20375

Th8.6 TUNABLE 35-200 GHz GYROTRON - S.N. Spark, A.D.R. Phelps and R.P. Winning, Dept of Physics and Appl Physics, U of Strathclyde, Glasgow G4 ONG, Scotland, UK

Th8.7 FIXED-FIELD ANALYSIS WITH VOLTAGE AND POWER TRADEOFFS FOR AN OPEN-CAVITY HARMONIC AUTO-RESONANT PENIOTRON (HARP) - R.C. Freundenberger, J.M. Baird and R.W. Grow, Microwave Dev and Physical Electron Lab, Dept of Elec Engr, U of Utah, Salt Lake City, UT 84112

Th8.8 DIELECTRIC LOADED WIDEBAND GYRO-TWT - K.C. Leou, D.B. McDermott and N.C. Luhmann, Jr., Elec Engr Dept, U of California, Los Angeles, CA 90024

Th8.9 CARM DESIGN FOR HEATING HIGH FIELD TOKAMAK - Q.S. Wang, D.B. McDermott, and N.C. Luhmann, Jr., U of California, Los Angeles, CA 90024 


\section{K. Chang, Presider}

F1.1 OPTICAL CONTROL OF MESFET AND HEMT MILLIMETER/MICROWAVE CIRCUITS - C. Kehwinkle, M.M. Gitin, R.D. Martinez, R.A. York, K.R. Haselton*, F.A. Wise*, R.C. Compton, School of Electrical Engineering, ${ }^{*}$ School of Applied and Engineering Physics, Cornell Univ, Ithaca, NY 14853

F1.2 DEVELOPMENT OF A MONOLITHIC $94 \mathrm{GHz} 360$ DEGREE QUASI-OPTICAL PHASE SHIFTER - L.B. Sjogren, N.C. Luhmann, Jr., R.J. Hwu, H-X. King, W. Wu, X.H. Qin, UCLA; M. Kim, D.B. Rutledge, Z. Popovic, R.M. Weikle, California Inst of Technology; W.W. Lam, TRW; B. Hancock, U. Lieneweg, J. Maserjian, JPL

F1.3 A COMPACT FARADAY ROTATOR FOR BEAM WAVEGUIDES - Steven J. Peters, Boeing Aerospace \& Electronics, High Tech Center, Box 3999, Seattle, WA 98124

F1.4 A MM-WAVE FOUR-PORT QUASI-OPTICAL CIRCULATOR - M.R. Webb, SRL DSTO, Dept of Physics, Univ of St. Andrews, Scotland

F1.5 ANALYSIS OF CYLINDRICAL RESONATOR FILLED WITH ANISOTROPIC MEDIUM - Y.Y. Tsai and A.S. Omar, Technische Universität Braunschweig, Institut für Hochfrequenztechnik, Postfach 33 29, D-3300 Braunschweig, West Germany

F1.6 SCATTERING PARAMETER MEASUREMENTS USING A THREE-PROBE MICROSTRIP CIRCUIT - Ming-Yi Li, Kai Chang and Thomas H. Sauter, Dept of Elec Engr, Texas A\&M Univ, College Station, TX 77843-3128

F1.7 FOUR PORT REFLECTOMETERS OPERATING AT Ka- AND W-BANDS - $\mathrm{N}$. Fourikis and N. Lioutas, Microwave Radar Div, Surveillance Research Lab, Defence Science and Technology Organization, South Australia 5108

F1.8 GLOBAL OPTIMISATION OF WAVEGUIDE E-PLANE MULTIPLEXERS - Jia-Sheng Hong and Jun-Ming Shi, Dept of Radio Engr, Fuzhou Univ, Fujian, PRC

F1.9 FULL-WAVE ANALYSIS OF CONNECTORS IN HIGH-SPEED COMPUTER PACKAGE - M. Cases, IBM Corp - Entry Systems Div, 1000 N.W. 51st St, Boca Raton, FL 33429; B. Rubin, IBM T.J. Watson Research Ctr, Yorktown Hights, NY 10598 


\section{F. Strumia, Presider}

F2.1 MANY WAVEGUIDES OPERATION OF A COMPACT CW OPTICALLY PUMPED FAR-INFRARED LASER - Alain Charlebois and Pierre Bernard, Natl Optics Inst, P.O. Box 9970, Sante-Foy (Quebec), G1V 4C5 Canada

F2.2 SPECTRAL LINEWIDTH OF P-TYPE GERMANIUM LASER - H.P. Roeser, G.W. Schwaab, R.U. Titz, Max-Planck Inst für Radioastronomie, D-5300 Bonn 1, FRG; S. Komiyama, S. Kuroda, I. Hosake, Univ. of Tokyo, Japan

F2.3 TuFIR SELFBROADENING MEASUREMENTS ON METHYL CYANIDE IN THE FREQUENCY RANGE FROM $770 \mathrm{GHz}$ TO $1300 \mathrm{GHz}$ - G.W. Schwaab, Max-Planck Inst, W. Germany; K.M. Evenson and L.R. Zink, Natl Inst for Standards and Technology, Boulder, CO 80303

F2.4 TRANSIENT ANALYSIS OF THE SPACE WAVE EQUATION BY THE METHOD OF BOUNDARY-ELEMENT IN TIME-DOMAIN - Jia-Sheng Hong, Dept of Radio Engr, Fuzhou Univ, Fujian, PRC

F2.5 FTIR SPECTROSCOPY OF THE $\mathrm{CD}_{3}$-ROCKING BANDS OF $\mathrm{CD}_{3} \mathrm{OH}$ AND ${ }^{13} \mathrm{CD}_{3} \mathrm{OH}$ - R.M. Lees, L.H. Xu, K.J. King, J.W.C. Johns, C. Young and T.J. Lees, Dept. Physics, Univ. New Brunswick, N.B., Canada

F2.6 FIR LASING AND SPECTROSCOPY IN THE $\mathrm{CH}_{3}$-ROCKING BAND OF 0-18 METHANOL - R.M. Lees, Saibei Zhao, M.A. Rommens, J.W.C. Johns, W. Lewis-Bevan, C. Young and T.J. Lees, Dept. Physics, Univ. New Brunswick, N.B., Canada

F2.7 THE HIGH RESOLUTION INFRARED FOURIER TRANSFORM SPECTRUM OF ${ }^{13} \mathrm{CD}_{3} \mathrm{OH}$ - D. Pereira, J.G.S. Moraes, A. Scalabrin, Inst de Fisica, Brasil; G. DiLonardo, L. Fusina, Inst di Chimica Fisica e Spettroscopia dell'Universita, Viale de Risorgimento 4, I-40136 Bologna, Italy

F2.8 MEASUREMENT AND ASSIGNMENTS OF NEW FIR LASER LINES FROM ${ }^{13} \mathrm{CD}_{3} \mathrm{OH}$ - D. Pereira, J.C.S. Moraes, A. Scalabrin, UNICAMP, 13081 Campinas S.P., Brasil; A. Moretti and F. Strumia, Dept di Fisica del Univ, 56.100 Pisa, Italy 
F2.9 ADIABATIC LIMITS OF THE MULTI-LEVEL RAMAN FAR-INFRARED LASERS S. Rai and J.R. Izatt, Dept of Physics, Univ Alabama, Tuscaloosa, AL 35487; J. Rai, US Army Missele Command, Redstone Arsenal, Huntsville, AL 35898

F2.10 FIR LASER EXPERIMENTS WITH $\mathrm{CH}_{3} \mathrm{C} 1$ and $\mathrm{CH}_{3} \mathrm{~F}-$ Wen-sen Zhu and Jerald R. Izatt, Dept of Physics, Univ Alabama, Tuscaloosa, Al 35487 


\section{SESSION F3}

Friday AM

PLASMA DIAGNOSTICS

Dec. 14

P. Woskov, Presider

F3.1 MILLIMETRE WAVE DIAGNOSTICS FOR THE JET PUMPED DIVERTOR PLASMA - D.V. Bartlett, A.E. Costley, R. Prentice, JET Joint Undertaking, Abingdon Oxon OX14 3EA, UK

F3.2 DEVELOPMENT OF A SUBMILLIMETER WAVE, CYCLOTRON HARMONIC GYROTRON AND ITS APPLICATION TO A SCATTERING MEASUREMENT OF PLASMA - T. Idehara, T. Tatsukawa and I. Ogawa, Faculty of Engr, Fukui Univ, Fukui 910, Japan; G.F. Brand, Univ of Sydney, Australia

F3.3 THE MOLECULAR SUBMILLIMETER LASER OPTION FOR COLLECTIVE THOMSON SCATTERING DIAGNOSTICS IN D-T BURNING TOKAMAKS - P.P. Woskov, D.R. Cohn, J.S. Machuzak and D.Y. Rhee, MIT Plasma Fusion Center, Cambridge, MA 02139; S.C. Han, Xsirius Superconductivity Inc., Scottsdale, AZ; R.H. Giles and J. Waldman, Univ of Lowell Research Foundation, Lowell, MA

F3.4 DEVELOPMENT OF HIGH POWER FIR LASERS FOR DIAGNOSTICS ON THE LARGE HELICAL DEVICE (LHD) - S. Okajima, K. Kawahata*, H. Takahashi*, H. Yamagishi, H. Maeda, Y. Hamada* and J. Fujita*, Appl. Phys. Lab, Chubu Univ, Kasugai, Aichi 487, Japan; *National Inst Fusion Sci, Nagoya, 464-01, Japan

F3.5 DENSITY PROFILE MEASUREMENT USING A MULTICHANNEL DIFLUOROMETHANE LASER INTERFEROMETER SYSTEM ON ATF - C.H. Ma, L.R. Baylor, D.P. Hutchinson, M. Murakami, K.L. Vander Sluis and J.B. Wilgen, Oak Ridge Natl Lab, Oak Ridge, TN 37831

F3.6 A $60 \mathrm{GHz}$ CROSS POLARIZATION SCATTERING EXPERIMENT TO INVESTIGATE MAGNETIC FLUCTUATIONS IN THE TORE SUPRA TOKAMAK - M. Paume, X.L. Zou and L. Laurent, Assoc. Euratom-CEA, DRFC/SPPF CEN Cadarache, F13108 SaintPaul-Lez-Durance, France

F3.7 A HIGH TEMPERATURE CALIBRATION SOURCE FOR ECE MEASUREMENTS K. Kawahata, M. Sakamoto and J. Fujita, Natl Inst for Fusion Sci, Nagoya 464-01, Japan; K. Sakai, Dept Appl Physics, Osaka Univ, Osaka 565, Japan

F3.8 MEASUREMENT OF ELECTRON DENSITY PROFILES ON HT-6M TOKAMAK BY 7-CHANNEL HCN LASER INTERFEROMETER - Gao Xiang and Guo Qiliang, Inst of Plasma Physics, Academia Sinica, P.O. Box 26, Hefei, PRC 
SESSION F4

Friday AM

POST DEADLINE II

Dec. 14

W. McGrath, Presider

F4.1 ULTRA COMPACT TAPER MODE CONVERTER DESIGN - F. Garin, G. Mourier, E. Giguet, J.M. Krieg, Thomson Tubes Electroniques, Velizy, France; E. Luneville, ECOLE Natl, Palaiseau

F4.2 EXTENSIVE EXPERIMENTAL RESULTS ON A $1 \mathrm{MW}, 8 \mathrm{GHz}$ GYROTRON AND THE TRANSMISSION LINE - P. Garin, G. Mourier, J.M. Krieg, A. Dubrovin, Thomson Tubes Electroniques, Velizy, France

F4.3 TEMPERATURE DEPENDENCE OF THE IR-ABSORBANCES OF DIPHENYLCARBINOL - M.I. Nasser and M.A. Moharram, Natl Res Ctr, Dokki, Cairo, Egypt

F4.4 A PULSED COHERENT $225 \mathrm{GHz}$ RADAR - R.W. McMillan, C.W. Trussel, Jr., R.A. Bohlander, J.C. Butterworth and R.E. Forsythe, GTRI, Georgia Inst of Tech, Atlanta, GA 30332

F4.5 BROADBAND DIRECTION FINDING AND ESM SYSTEM $18 \mathrm{GHz}$ to $110 \mathrm{GHz}-$ F. Liu, W. Sun, M. Chen, C. Chandler, K. Liu, S. Min, A. Chen, S. Chien, MM-Wave Technology, Inc., 1461 S. Balboa Ave, Ontario, CA 91761 


\begin{tabular}{|c|c|c|c|c|c|}
\hline Name & Sess & $\mathrm{Pg}$ & Name & Sess & $\mathrm{Pg}$ \\
\hline Abba, $P$. & M3. 9 & 53 & Barsanti, M.L. & $\begin{array}{l}\text { T } 8.6 \\
\text { Th } 4.2\end{array}$ & $\begin{array}{l}330 \\
572\end{array}$ \\
\hline Abdalla, H., Jr. & W1.1 & 336 & & & \\
\hline Adamson, D.A. & T5.1 & 240 & Bartlett, D.V. & F3.1 & 744 \\
\hline Afsar, M.N. & $\mathrm{T} 2.2$ & 181 & Basten, M.A. & $\operatorname{Th} 4.3$ & 575 \\
\hline & $\begin{array}{l}\text { T2. } 4 \\
\text { Th2.4 }\end{array}$ & $\begin{array}{l}187 \\
544\end{array}$ & Batanov, V.A. & $\begin{array}{l}\operatorname{Th} 7.7 \\
\operatorname{Th} 3.10 \\
\operatorname{Th} 3.1\end{array}$ & \\
\hline Agahi, F. & T5. 4 & 248 & & $\operatorname{Th} 3.7$ & \\
\hline Agarwal, R. & w6. 2 & 458 & Baylor, L.R. & F3.5 & \\
\hline Agosti, G. & $\mathrm{T} 8.3$ & 321 & Beaudin, G. & $\begin{array}{l}\text { M7. } 5 \\
\text { M3.9 }\end{array}$ & $\begin{array}{l}127 \\
53\end{array}$ \\
\hline $\begin{array}{l}\text { Ahn, S. } \\
\text { Aksenov, M.Yu. }\end{array}$ & $\begin{array}{l}\text { Th } 4.8 \\
\text { Th7 } 7\end{array}$ & 590 & Berberich, $\mathrm{P}$. & M6. 1 & 101 \\
\hline Alberti, $S$. & T8.3 & $\begin{array}{l}321 \\
425\end{array}$ & Bergeron, G. & Th 4.4 & 578 \\
\hline Alexeff, I. & $\begin{array}{l}\text { M4. } 6 \\
\text { M4.7 } \\
\text { W7. } 4\end{array}$ & $\begin{array}{l}71 \\
74 \\
481\end{array}$ & $\begin{array}{l}\text { Bernard, } P \text {. } \\
\text { Best, } T \text {. }\end{array}$ & F2.1 & 717 \\
\hline Ali-Ahmad, $W$ & $\begin{array}{l}\text { Th5 } 5.7 \\
\operatorname{Th} 5.6\end{array}$ & $\begin{array}{l}617 \\
614\end{array}$ & Betz, J. & $\begin{array}{l}\text { M6.3 } \\
\text { M6.4 }\end{array}$ & $\begin{array}{l}104 \\
107\end{array}$ \\
\hline Allen, $B$. & $\mathrm{T} 1.9$ & 175 & Bhasin, K.B. & M6. 8 & \\
\hline Andreyev, Y.V. & $\operatorname{Th} 6.3$ & 631 & Bidwell, S.W. & M8. 3 & 140 \\
\hline Antonsen, T.M., Jr. & $\begin{array}{l}\mathrm{M} 8.3 \\
\mathrm{~T} 4.2\end{array}$ & $\begin{array}{l}140 \\
222\end{array}$ & Bing, wei & M7. 7 & 132 \\
\hline & M4.2 & 62 & Birch, J.R. & T5.1 & 240 \\
\hline & $\begin{array}{l}\text { W8. } 8 \\
\text { W8.7 }\end{array}$ & $\begin{array}{l}511 \\
508\end{array}$ & & W6. 4 & 464 \\
\hline & W8. & & Birk, M. & M3. 3 & \\
\hline Aoki, T. & M7.3 & 122 & Bishop, W.L. & w3. 3 & 392 \\
\hline Armstrong, C.M. & $\operatorname{Th} 4.2$ & $\begin{array}{l}572 \\
122\end{array}$ & Blank, M. & T3.4 & 210 \\
\hline $\begin{array}{l}\text { Aruga, } \mathrm{T} . \\
\text { Askenazy, S. }\end{array}$ & $\begin{array}{l}\text { M7. } 3 \\
\text { M2. } 3\end{array}$ & $\begin{array}{l}124 \\
26\end{array}$ & Blanton, S.H. & M2. 1 & \\
\hline & & & Bluem, $\mathrm{H}$. & M8. 1 & 135 \\
\hline Avakian, M. & Th2.9 & & & $\begin{array}{l}M 8.2 \\
M 8.6\end{array}$ & $\begin{array}{l}137 \\
146\end{array}$ \\
\hline Baird, J.M. & $\begin{array}{l}\text { T6.4 } \\
\operatorname{Th} 8.7\end{array}$ & $\begin{array}{l}280 \\
684\end{array}$ & Boardman, S.R. & $\operatorname{Th} 3.9$ & \\
\hline Bao, $x$. & M5. 3 & 85 & Bogachenkov, V.A. & M8. 5 & \\
\hline Barnett, L.R. & $\mathrm{T} 6.4$ & 280 & Bohlander, R.A. & F 4.4 & 771 \\
\hline Barsanti, M.L. & $\operatorname{Th} 4.4$ & 578 & Bohn, C.L. & M2. 5 & 29 \\
\hline
\end{tabular}

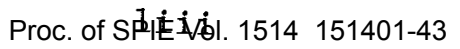




\begin{tabular}{|c|c|c|c|c|c|}
\hline Name & Sess & Pg & Name & Sess & Pg \\
\hline Bookse, J.H. & $\begin{array}{l}\text { T } 4.4 \\
\text { T }\end{array}$ & 228 & Caplan, M. & Th4.3 & 575 \\
\hline \multirow[t]{2}{*}{ Booske, J. } & $\mathrm{T} 4.5$ & 231 & Carelli, G. & w3. 1 & 386 \\
\hline & & & & $\operatorname{Th} 3.8$ & 565 \\
\hline Boric, 0 & T5. 5 & 251 & & Th3.6 & 562 \\
\hline \multirow[t]{2}{*}{ Borie, E. } & W8.1 & 493 & Carmel, Y. & M1. 2 & 4 \\
\hline & $\operatorname{Th} 4.9$ & 593 & & M8. 3 & 140 \\
\hline \multirow[t]{3}{*}{ Boulais, $\mathrm{K}$. } & w2. 6 & 375 & Cases, M. & $\mathrm{F} 1.9$ & 714 \\
\hline & w8. 6 & & & & \\
\hline & Th 4.5 & 581 & Casey, J.A. & T3. 4 & 210 \\
\hline Bourget, L.P. & $\mathrm{T} 6.6$ & 285 & Casper, D.A. & W5 . 2 & 434 \\
\hline \multirow[t]{3}{*}{ Brand, G.F. } & W8. 2 & 496 & Chaloupka, H. & M6. 1 & 101 \\
\hline & F3.2 & 747 & & & \\
\hline & & & Chandra, $\mathrm{K}$. & T1.1 & 152 \\
\hline \multirow[t]{2}{*}{ Bres, $M$. } & M4. 5 & 68 & & & \\
\hline & M4. 4 & 65 & Chang, J. & $\begin{array}{l}\text { Th1. } 7 \\
\text { Th5 } 11\end{array}$ & 532 \\
\hline Brown, $F$. & w3. 4 & 395 & & & \\
\hline \multirow{2}{*}{ Brunner, B. } & T1.9 & 175 & Chang, $\mathrm{K}$. & $\begin{array}{l}\text { M7.7 } \\
\text { Th1.3 }\end{array}$ & $\begin{array}{l}132 \\
520\end{array}$ \\
\hline & 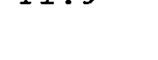 & 1. & & F1. 6 & 708 \\
\hline \multirow[t]{2}{*}{ Brunone, D. } & T1.9 & 175 & & & \\
\hline & $\operatorname{Th} 1.4$ & 523 & Chang, S.F. & T4.5 & $\begin{array}{l}231 \\
228\end{array}$ \\
\hline \multirow{2}{*}{ Bruschi, A. } & $\mathrm{T} 7.3$ & & & & 220 \\
\hline & & & Charlebois, A. & $\mathrm{F} 2.1$ & 717 \\
\hline Budhani, R. & M6.2 & & Chen, C.M. & $\mathrm{T} 2.9$ & 201 \\
\hline \multirow[t]{2}{*}{ Bumble, B. } & T5. 3 & 245 & & & \\
\hline & & & Chen, K.S. & Th5.9 & \\
\hline Bunch, K.J. & T7. 7 & 313 & Chen $Y-Y$ & M1 6 & 15 \\
\hline \multirow[t]{2}{*}{ Bunshah, R. } & T5.11 & 268 & Concis 1 & M1. 5 & 13 \\
\hline & & & & Th5.2 & 602 \\
\hline Buratti, P. & Th2 2.7 & & & & \\
\hline \multirow{2}{*}{ Burghoorn, J. } & W2. 4 & 369 & Chen, 1. & 18. & \\
\hline & & & Cheung, P. & W7. 5 & 484 \\
\hline \multirow[t]{2}{*}{ Butterworth, J.C. } & F 4.4 & 771 & & & \\
\hline & & & Chi, H. & T2. 2 & 181 \\
\hline Byers, J.A. & Th2. 2 & 538 & & Th2. 4 & 544 \\
\hline \multirow[t]{2}{*}{ Cai, J. } & M6. 5 & 110 & Choe, J.Y. & W8. 6 & \\
\hline & & & & W2. 6 & 375 \\
\hline Cai, S-Y. & W8. 7 & 508 & & Th 4.5 & 581 \\
\hline Cai, S.z. & M2 . 6 & 32 & Choi, J.J. & M8. 4 & 143 \\
\hline \multirow[t]{3}{*}{ Calame, J. } & $\operatorname{Th} 8.2$ & 669 & Chou, K. & T5.11 & 268 \\
\hline & $\operatorname{Th} 4.10$ & 596 & & & \\
\hline & & & Chrisey, D.B. & M2. 4 & \\
\hline \multirow[t]{2}{*}{$\mathrm{CaO}, \mathrm{H}$. } & $\mathrm{T} 8.3$ & 321 & & M2. 3 & 26 \\
\hline & $\operatorname{Th} 2.1$ & 535 & Christian, M. & T1. 6 & 166 \\
\hline
\end{tabular}




\begin{tabular}{|c|c|c|c|c|c|}
\hline Name & Sess & $\mathrm{Pg}$ & Name & Sess & $\mathrm{Pg}$ \\
\hline \multirow{2}{*}{ Chu, T.S. } & M4. 4 & 65 & Dellis, A.N. & $\mathrm{T} 6.5$ & 283 \\
\hline & M4. 5 & 68 & & Th2.5 & 547 \\
\hline \multirow[t]{3}{*}{ Chun, S.T. } & w2. 6 & 375 & DeMey, $\mathrm{K}$. & M6. 6 & 113 \\
\hline & W8. 6 & & & & \\
\hline & $\operatorname{Th} 4.5$ & 581 & Demin, A.I. & Th7.7 & \\
\hline Cirant, $s$. & $\mathrm{T} 7.3$ & & deOliverira, A.M.S. & $\mathrm{W} 1.1$ & 336 \\
\hline Cohn, D.R. & F3.3 & 750 & Deschamps, A. & M3. 9 & 53 \\
\hline Cole, R.S. & T1.7 & 169 & Deshpandey, C. & T5.11 & 268 \\
\hline Collins, R.T. & M2. 1 & & Destler, W.W. & M8. 3 & 140 \\
\hline \multirow[t]{2}{*}{ Compton, R.C. } & Th5. 3 & 605 & DiLonardo, G. & $\mathrm{F} 2.7$ & 732 \\
\hline & $\mathrm{F} 1.1$ & 693 & & & \\
\hline \multirow{2}{*}{ Connor, K.A. } & W6. 6 & 470 & DiMarzio, D. & 16.2 & \\
\hline & & & Ding, L. & Th7.9 & 661 \\
\hline Cooperstein, J.M. & $\mathrm{T} 8.7$ & 333 & & w6. 5 & 467 \\
\hline Costley, A.E. & F3.1 & 744 & Diniz, C.M., Jr. & $\mathrm{w} 1.3$ & 341 \\
\hline Crabtree, G.W. & M2. 1 & & Doane, J.L. & T3. 5 & 213 \\
\hline \multirow{4}{*}{ Crowe, T.W. } & W3. 6 & 401 & Dobrowolski, w. & W2. 9 & 383 \\
\hline & W7. 3 & 478 & & & \\
\hline & w3. 3 & 392 & Donkor, E. & M5. 3 & 85 \\
\hline & W3. 8 & 407 & & $\begin{array}{l}\text { M1.8 } \\
\operatorname{Th} 6.4\end{array}$ & 20 \\
\hline \multirow{2}{*}{ Crowe, w. } & W7. 1 & 473 & & & \\
\hline & & & Dubrovin, A. & F 4.2 & 768 \\
\hline CRPP/ABB Group & W4.1 & 410 & & F5.2 & \\
\hline Culbertson, J.C. & M2. 4 & & Dudas, A.J. & T8. 8 & \\
\hline Cypher, S.R. & T5. 3 & 245 & Dufaux, F. & W4. 6 & 425 \\
\hline \multirow{2}{*}{ Czarnaski, M. } & $\operatorname{Th} 4.4$ & 578 & Dumbrajs, 0 . & $\mathrm{T} 3.3$ & 207 \\
\hline & & & & W8. 4 & 502 \\
\hline \multirow{2}{*}{ Daly, K. } & T5.11 & 268 & & W8. 1 & 493 \\
\hline & & & & W4. 5 & 422 \\
\hline \multirow[t]{5}{*}{ Dammert $z, G$. } & W8.1 & 493 & & & \\
\hline & T7. 4 & 304 & Dumelow, T. & $\mathrm{T} 2.1$ & 178 \\
\hline & W8. 4 & 502 & & & \\
\hline & w8.1 & 493 & Dyer, $F$. & M4. 6 & 71 \\
\hline & & & & M4.7 & 74 \\
\hline \multirow[t]{3}{*}{ Danly, B.G. } & M4. 4 & 65 & & W7. 4 & 481 \\
\hline & M4.5 & 68 & & & \\
\hline & $\operatorname{Tn} 8.1$ & 654 & Dyson, $\mathrm{H} . \mathrm{B}$. & W6.7 & \\
\hline DeBolt, $R$. & M3.10 & 56 & East, J. & T5. 6 & 254 \\
\hline deGroot, P. & M6. 6 & 113 & Eisele, H. & Th 6.2 & 626 \\
\hline Delayen, J.R. & M2. 5 & 29 & Eleftheriades, G. & Th5.6 & 614 \\
\hline
\end{tabular}




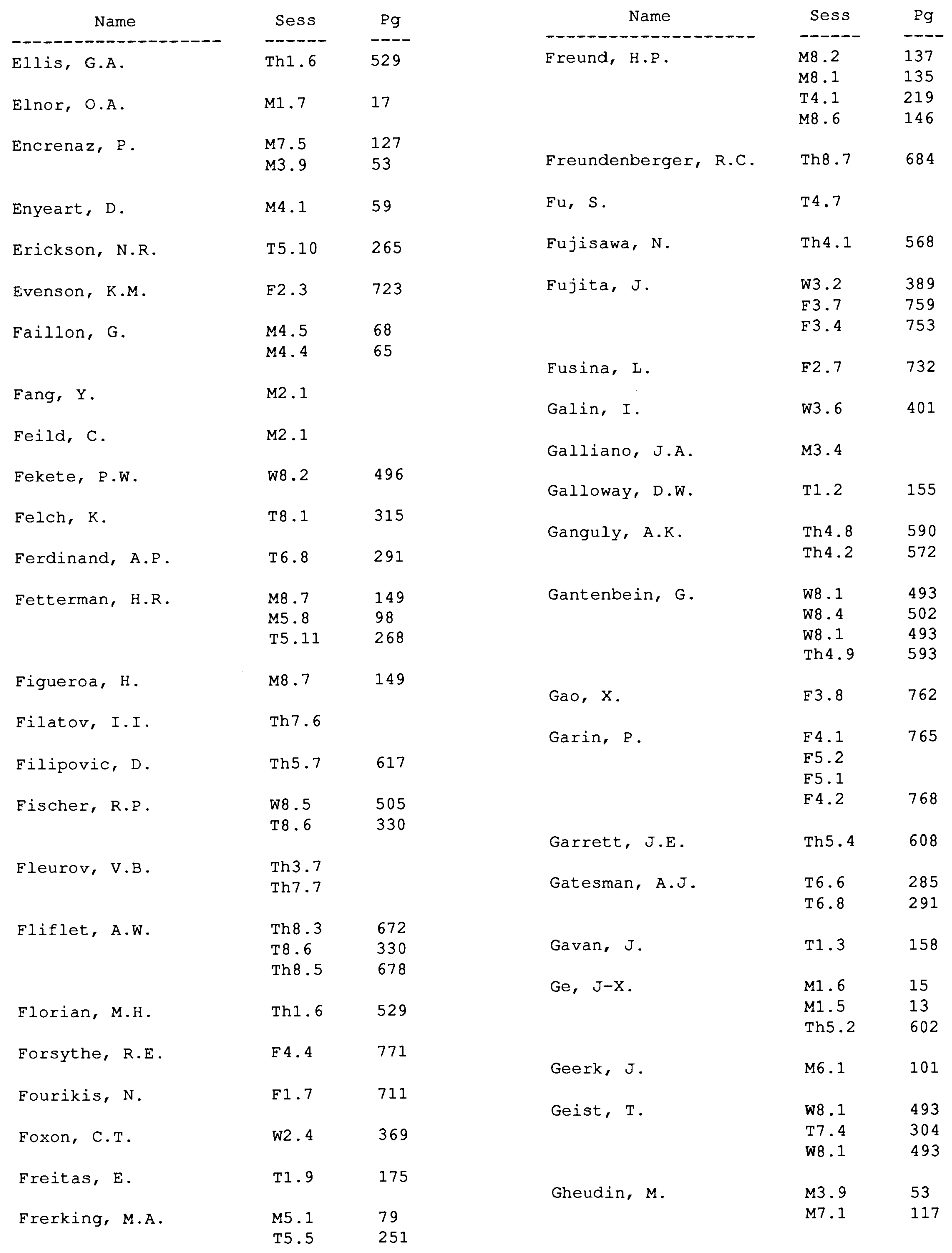

Proc. of SPIE V/\$1i1514 151401-46 


\begin{tabular}{|c|c|c|c|c|c|}
\hline Name & Sess & $\mathrm{Pg}$ & Name & Sess & $\mathrm{Pg}$ \\
\hline Ghorannevis, M. & Th2.9 & --- & Groves, F.M. & $\begin{array}{ll}-\cdots \\
M 3.5\end{array}$ & $-\cdots$ \\
\hline \multirow[t]{3}{*}{ Giarola, A.J. } & $\mathrm{w} 1.3$ & 341 & Grow, R.W. & $\mathrm{T} 6.4$ & 280 \\
\hline & W1. 7 & 353 & & $\mathrm{~T} 7.7$ & 313 \\
\hline & & & & Th8.7 & 684 \\
\hline \multirow{2}{*}{ Giguet, E. } & F 5.1 & & & & \\
\hline & F 4.1 & 765 & Gubser, D.U. & M2. 2 & 23 \\
\hline \multirow[t]{5}{*}{ Giles, R.H. } & F3.3 & 750 & Gundersen, M.A. & M8. 7 & 149 \\
\hline & $\mathrm{T} 6.8$ & 291 & & & \\
\hline & $\mathrm{T} 6.6$ & 285 & Guo, H. & M1. 2 & 4 \\
\hline & M2. 7 & 35 & & & \\
\hline & & & Guo, $Q$. & F3.8 & 762 \\
\hline \multirow[t]{2}{*}{ Gilgenbach, R.M. } & M8. 4 & 143 & & & \\
\hline & & & Guss, W.C. & T8. 4 & 324 \\
\hline \multirow[t]{2}{*}{ Gitin, M.M } & F1.1 & 693 & & W4. 3 & 416 \\
\hline & & & & Th 4.3 & 575 \\
\hline \multirow[t]{2}{*}{ Goiran, $M$. } & M2. 3 & 26 & & & \\
\hline & & & Hacker, J.B. & T5. 5 & 251 \\
\hline \multirow{2}{*}{ Gold, S,H. } & Th8.4 & 675 & & & \\
\hline & Th8.3 & 672 & Haddad, G.I. & T5. 6 & 254 \\
\hline Goldsmith, P.F. & $\mathrm{T} 5.10$ & 265 & Hadwin, L.J. & w6. 6 & 470 \\
\hline Gong, Yaqian & $\mathrm{T} 5.12$ & & Hamada, Y. & F3. 4 & 753 \\
\hline \multirow{2}{*}{ Goodman, T. } & $\mathrm{T} 8.3$ & 321 & Han, S.C. & F3.3 & 750 \\
\hline & & & & M2. 7 & 35 \\
\hline \multirow{2}{*}{ Gorbovitskiy, B.M. } & Th7.6 & & & & \\
\hline & M6. 8 & & Hancock, B. & Th1.8 & \\
\hline Gordon, W.L. & & & Hangyo, $\mathrm{M}$. & $\mathrm{T} 6.1$ & 271 \\
\hline \multirow[t]{2}{*}{ Gorfinkel, V.B. } & Th7.6 & & & & \\
\hline & & & Hargreaves, T.A. & Th4. 4 & 578 \\
\hline \multirow[t]{2}{*}{ Gorshunov, B.P. } & M6. 7 & 116 & & T8.7 & 333 \\
\hline & & & & $\mathrm{T} 8.6$ & 330 \\
\hline \multirow[t]{2}{*}{ Govorun, V.M. } & Th7.7 & & & Th8.5 & 678 \\
\hline & & & & Th 4.2 & 572 \\
\hline \multirow[t]{2}{*}{ Goy, P. } & $\mathrm{T} 1.8$ & 172 & & & \\
\hline & & & Hartemann, F. & M4. 5 & 68 \\
\hline \multirow[t]{3}{*}{ Grammer, $W$. } & T5. 4 & 248 & & M4. 4 & 65 \\
\hline & T5. 9 & 262 & & & \\
\hline & & & Harvey, A. & $\mathrm{T} 2.8$ & 198 \\
\hline \multirow{8}{*}{ Granatstein, V.L. } & M8. 6 & 146 & & & \\
\hline & M8. 3 & 140 & Hasegawa, N. & $\mathrm{T} 6.1$ & 271 \\
\hline & M1. 2 & 4 & & & \\
\hline & $\mathrm{T} 8.7$ & 333 & Haselton, K.R. & $\mathrm{F} 1.1$ & 693 \\
\hline & W4.7 & 428 & & & \\
\hline & Th8.2 & 669 & Hattori, $T$. & $\mathrm{T} 6.1$ & 271 \\
\hline & $\operatorname{Th} 4.10$ & 596 & & & \\
\hline & & & Hausamann, D. & M3. 3 & \\
\hline \multirow[t]{4}{*}{ Grimm, T.L. } & T8. 4 & 324 & & & \\
\hline & $\mathrm{T} 8.5$ & 327 & Hayashi, K. & $\mathrm{T} 8.2$ & 318 \\
\hline & W4. 3 & 416 & & & \\
\hline & & & Haycocks, P.R. & T5.7 & 257 \\
\hline \multirow{2}{*}{ Grosch, J. } & M3. 8 & 50 & & & \\
\hline & T1. 8 & 172 & Hazel, G. & T 8.7 & 333 \\
\hline
\end{tabular}




\begin{tabular}{|c|c|c|c|c|c|}
\hline Name & Sess & $\mathrm{Pg}$ & Name & Sess & $\mathrm{Pg}$ \\
\hline$-----------\infty-----$ & ---- & --- & 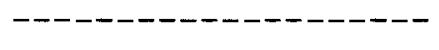 & ------ & --- \\
\hline $\mathrm{He}, \mathrm{I}$. & $\mathrm{W} 1.2$ & 338 & Hoyt, R.P. & W3. 4 & 395 \\
\hline \multirow[t]{4}{*}{ Heidinger, $R$. } & $\mathrm{T} 2.3$ & 184 & $\mathrm{Hu}, \mathrm{K}$. & $\mathrm{T} 4.7$ & \\
\hline & W6. 4 & 464 & & & \\
\hline & $\mathrm{T} 6.2$ & 274 & Huang, J. & Th5.11 & \\
\hline & & & & $\operatorname{Th} 1.7$ & 532 \\
\hline \multirow[t]{2}{*}{ Henle, w. } & W5. 4 & 440 & & & \\
\hline & & & Huey, $\mathrm{H}$. & T8.1 & 315 \\
\hline \multirow[t]{2}{*}{ Herlach, F. } & M6. 6 & 113 & & & \\
\hline & & & Hufford, G. & M3.10 & 56 \\
\hline \multirow[t]{2}{*}{ Hernandez, $\mathrm{A}$. } & W6. 3 & 461 & & & \\
\hline & & & Huguenin, D. & M7. 6 & 130 \\
\hline \multirow[t]{2}{*}{ Herrmann, w. } & w3.7 & 404 & & & \\
\hline & & & Hummer, $\mathrm{K}$. & M7. 7 & 132 \\
\hline \multirow[t]{2}{*}{ Hess, C. } & T8.1 & 315 & & & \\
\hline & & & Hunt, B.D. & T5. 3 & 245 \\
\hline \multirow[t]{2}{*}{ Hinks, D.G. } & M2. 1 & & & & \\
\hline & & & Hutchinson, D.P. & F3. 5 & \\
\hline \multirow[t]{2}{*}{ Hirata, $Y$. } & $\mathrm{T} 8.2$ & 318 & & & \\
\hline & & & Hwu, R.J. & M5. 2 & 82 \\
\hline \multirow[t]{2}{*}{ Hiromoto, N. } & M7.2 & 120 & & $\mathrm{~F} 1.2$ & 696 \\
\hline & M7. 3 & 122 & & $\operatorname{Th} 1.8$ & \\
\hline Hirshfield, J.L. & W4.8 & 430 & Idehara, $T$. & F3.2 & 747 \\
\hline \multirow[t]{3}{*}{ Hochschild, G. } & w8.1 & 493 & Imae, $\mathrm{M}$. & M7. 4 & 124 \\
\hline & T7. 4 & 304 & & & \\
\hline & W8.1 & 493 & Inatani, $\mathrm{J}$. & M5. 5 & 91 \\
\hline Hodgetts, $\mathrm{T}$. & T5.1 & 240 & Inoue, $\mathrm{N}$. & $\mathrm{T} 6.3$ & 277 \\
\hline \multirow[t]{2}{*}{ Hofmann, A. } & $\operatorname{Th} 2.3$ & 541 & Ioli, N. & Th3 6 & 562 \\
\hline & & & & Th3.8 & 565 \\
\hline \multirow[t]{2}{*}{ Hogan, B. } & Th8.2 & 669 & & & \\
\hline & & & Isaak, B. & T8. 3 & 321 \\
\hline \multirow[t]{2}{*}{ Hogge, J.P. } & T8.3 & 321 & & & \\
\hline & $\operatorname{Th} 2.1$ & 535 & Islam, M.S. & W7. 5 & 484 \\
\hline \multirow[t]{2}{*}{ Holenstein, A. } & M7. 6 & 130 & Itabe, T. & M7. 2 & 120 \\
\hline & & & & M7. 3 & 122 \\
\hline \multirow[t]{2}{*}{ Holtzberg, F. } & M2. 1 & & & & \\
\hline & & & Itoh, $\mathrm{T}$. & W5. 1 & 431 \\
\hline \multirow[t]{3}{*}{ Hong, J-S. } & F2. 4 & & & W7. 5 & 484 \\
\hline & F1. 8 & & & & \\
\hline & & & Itoh, Y. & T8.2 & 318 \\
\hline \multirow[t]{2}{*}{ Hong, $\mathrm{K}$. } & w8. 2 & 496 & & & \\
\hline & & & Ivanov, Yu L. & Th6.10 & \\
\hline \multirow[t]{2}{*}{ Hong, w. } & W5. 6 & 446 & & & \\
\hline & & & Izatt, J.R. & F2.9 & 738 \\
\hline \multirow[t]{2}{*}{ Hopman, $\mathrm{H}$. } & $\operatorname{Th} 4.1$ & 568 & & F2.10 & 741 \\
\hline & & & & $\operatorname{Th} 3.2$ & 551 \\
\hline Horowitz, J.S. & M2. 4 & & & & \\
\hline & & & Jackson, R.H. & M8.1 & 135 \\
\hline Horwitz, J.S. & M2. 3 & 26 & & M8. 2 & 137 \\
\hline & & & & $M 8.6$ & 146 \\
\hline Hosako, I. & $\mathrm{F} 2.2$ & 720 & & & \\
\hline$x^{2}+x^{2}$ & & & Jacob, A. & M1. 7 & 17 \\
\hline Hosokawa, M. & T8.3 & 321 & & & \\
\hline
\end{tabular}




\begin{tabular}{|c|c|c|c|c|c|}
\hline Name & Sess & $\mathrm{Pg}$ & Name & Sess & $\mathrm{Pg}$ \\
\hline 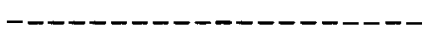 & ------ & ---- & 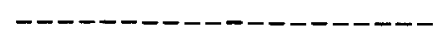 & ----- & --- \\
\hline Jacobs, A. & T3.1 & 204 & Kang, S.K. & $\mathrm{T} 2.1$ & 178 \\
\hline Jain, F. & M5. 3 & 85 & Kapitanov, A.B. & Th7 7 & \\
\hline \multirow[t]{2}{*}{ Jain, F.C. } & $\begin{array}{l}\text { M1. } 8 \\
\operatorname{Th} 6.4\end{array}$ & 20 & Kariya, T. & T8. 2 & 318 \\
\hline & & & Kasibhotla, s. & W6. 6 & 470 \\
\hline \multirow[t]{3}{*}{ Jamnejad, V. } & Th1.7 & 532 & & & \\
\hline & Th5.11 & & Kasparek, W. & T3.2 & \\
\hline & & & & T7. 6 & 310 \\
\hline \multirow[t]{2}{*}{ Janssen, $P$. } & W2. 8 & 381 & & W5. 3 & 437 \\
\hline & M6. 6 & 113 & & Th2.1 & 535 \\
\hline Javadi, H.H.S. & T5.3 & 245 & Katehi, L.P. & Th5. 6 & 614 \\
\hline Javalagi, S. & M5. 4 & 88 & Kawaguchi, N. & M7. 4 & 124 \\
\hline Javon, C. & $\operatorname{Th} 2.8$ & 548 & Kawahata, $\mathrm{K}$. & F3.7. & 759 \\
\hline \multirow[t]{2}{*}{ Jegou, J.R. } & M3. 9 & 53 & & & \\
\hline & & & Kawahate, $\mathrm{K}$. & W3.2 & 389 \\
\hline Jenkinson, H. & & & Kelly, W.M. & T5. 2 & 242 \\
\hline \multirow[t]{2}{*}{ Jha, A.R. } & T1.5 & 163 & & & \\
\hline & Th5.1 & 599 & Kennedy, w.L. & M2. 5 & 29 \\
\hline \multirow[t]{2}{*}{ Jodicke, B. } & T8.3 & 321 & Kesselring, R. & W7. 2 & 475 \\
\hline & & & & Th7.5 & 655 \\
\hline \multirow{2}{*}{ Joe, J. } & T 4.4 & 228 & & Th3.5 & 559 \\
\hline & T 4.5 & 231 & & $\operatorname{Th} 7.3$ & 651 \\
\hline \multirow[t]{3}{*}{ Johns, J.W.C. } & $\mathrm{F} 2.5$ & 726 & Khan, H.M. & M5. 7 & \\
\hline & F2. 6 & 729 & & & \\
\hline & & & Kim, C.W. & T6.9 & 294 \\
\hline Johns, S.L. & W6.7 & & $\mathrm{Kim}$ & M1 3 & 7 \\
\hline \multirow[t]{2}{*}{ Johnston, S.L. } & $\operatorname{Th} 6.7$ & 638 & & & \\
\hline & & & Kim, M. & $\mathrm{F} 1.2$ & 696 \\
\hline Jones, w. & $\operatorname{Th} 1.4$ & 523 & & $\operatorname{Th} 1.5$ & 526 \\
\hline Jongewaard, E. & $\mathrm{T} 8.1$ & 315 & Kim, T.W. & T5.11 & 268 \\
\hline Jory, H. & $\mathrm{T} 8.1$ & 315 & Kimmitt, $\mathrm{M}$. & M8. 1 & 135 \\
\hline Jostingmeier, A. & w1.11 & 362 & Kimura, H. & $\operatorname{Th} 4.1$ & 568 \\
\hline Jungwirt, $G$. & w2. 5 & 372 & Kinasewitz, R.T. & Th 6.5 & \\
\hline Juntze, M. & W8.1 & 493 & Kinder, $\mathrm{H}$. & M6.1 & 101 \\
\hline \multirow[t]{5}{*}{ Kalin, A.W. } & W7. 2 & 475 & King, $\mathrm{H}-\mathrm{X}$. & $\mathrm{F} 1.2$ & 696 \\
\hline & Th7.3 & 651 & & & \\
\hline & $\operatorname{Th} 3.5$ & 559 & King, K.J. & F2. 5 & 726 \\
\hline & Th7.5 & 655 & & & \\
\hline & & & King, N. & T5.8 & 259 \\
\hline Kalonia, $\mathrm{K}$. & M5. 3 & 85 & Kinkhead, A.K. & Th 8.3 & 672 \\
\hline Kaminski, J.P. & M4.1 & 59 & & & \\
\hline
\end{tabular}




\begin{tabular}{|c|c|c|c|c|c|}
\hline Name & Sess & $\mathrm{Pg}$ & Name & Sess & $\mathrm{Pg}$ \\
\hline 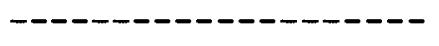 & ----- & --- & $-\cdots-\cdots$ & ------ & --- \\
\hline Kirkman-Amemiya, G. & M8. 7 & 149 & Kubo, S. & $\mathrm{T} 8.3$ & 321 \\
\hline Kirkpatrick, D.A. & Th8.3 & 672 & Kulke, B. & $\operatorname{Th} 4.3$ & 575 \\
\hline Kitazawa, T. & W5. 1 & 431 & Kumar, G.K. & M5. 4 & 88 \\
\hline Klaassen, T.O. & W2. 4 & 369 & Kumirc, H. & W5. 4 & 440 \\
\hline Klein, $\mathrm{N}$ & M6. 1 & 101 & Kumlin, A. & $\mathrm{T} 6.2$ & 274 \\
\hline \multirow[t]{6}{*}{ Kneubuhl, F.K. } & $\begin{array}{l}\text { M7. } 6 \\
\text { W7. } 2\end{array}$ & $\begin{array}{l}130 \\
475\end{array}$ & Kuntze, M. & W8.1 & 493 \\
\hline & W3. 7 & 404 & Kuo, C.W. & W5.1 & 431 \\
\hline & $\operatorname{Th} 7.1$ & 649 & & & \\
\hline & Th3.5 & 559 & Kuo, S.P. & M3. 7 & 47 \\
\hline & Th7.5 & 655 & & M1.3 & 7 \\
\hline & Th7.3 & 651 & & M3. 5 & \\
\hline \multirow[t]{2}{*}{ Kobayashi, H. } & M5. 5 & $\begin{array}{l}91 \\
277\end{array}$ & Kuroda, s. & F2.2 & 720 \\
\hline & & & Kurtz, J.L. & M3. 8 & 50 \\
\hline Kodaira, s. & & & Kyser, R.K. & $\operatorname{Th} 4.2$ & 572 \\
\hline \multirow[t]{2}{*}{ Koh，K.L. } & M3. 5 & & & & \\
\hline & & & Lammers, U.H.W. & T1. 4 & 160 \\
\hline \multirow[t]{2}{*}{ Komiyama, s. } & F2.2 & 720 & & & \\
\hline & & & Lane, T.L. & T1.2 & 155 \\
\hline Komuro, M. & T8.2 & 318 & & $\mathrm{~T} 1.6$ & 166 \\
\hline \multirow[t]{2}{*}{ Kong, K-S. } & W5.1 & 431 & Latham, P.E. & M4. 2 & 62 \\
\hline & & & & M8.3 & 140 \\
\hline \multirow[t]{2}{*}{ Konishi, Y. } & M5. 5 & 91 & & W4.7 & 428 \\
\hline & & & & Th8.2 & 669 \\
\hline Kopiczynski, T.L. & $\operatorname{Th} 7.5$ & 655 & & Th 4.10 & 596 \\
\hline Kopp, K.W. & $\mathrm{T} 7.6$ & 310 & Lau, K.M. & T5. 4 & 248 \\
\hline Kotov, V.D. & $\operatorname{Th} 6.3$ & 631 & Laue, I. & W2. 9 & 383 \\
\hline Kou, C.S. & $\operatorname{Th} 4.7$ & 587 & Laurent, L. & F3. 6 & 756 \\
\hline \multirow[t]{2}{*}{ Koyama, Y. } & M7. 4 & 124 & Lawson, W. & W4.7 & 428 \\
\hline & & & & Th 4.10 & 596 \\
\hline Kozlov, G.V. & M6. 7 & 116 & & Th8.2 & 669 \\
\hline Kreischer, $\mathrm{K}$. & T3.4 & 210 & Lednum, E.E. & w8.9 & 514 \\
\hline \multirow[t]{4}{*}{ Kreischer, K.E. } & W4. 3 & 416 & LeDuc, H.G. & T5. 3 & 245 \\
\hline & T8. 5 & 327 & & & \\
\hline & T8.4 & $\begin{array}{l}324 \\
575\end{array}$ & Lee, M.C. & M3. 5 & \\
\hline & $\operatorname{Inn} 4.3$ & ( & Lees, R.M. & F2. 5 & 726 \\
\hline \multirow[t]{4}{*}{ Krieg, J.M. } & F5.1 & & & F2. 6 & 729 \\
\hline & F5.2 & & & & \\
\hline & F 4.1 & 765 & Lees, T.J. & F2. 6 & 729 \\
\hline & $\mathrm{F} 4.2$ & 768 & & F2. 5 & 726 \\
\hline Kropf, R. & w2. 5 & 372 & Lei, L. & Th 6.1 & \\
\hline
\end{tabular}

Proc. of SPIE Vol. 1514 151401-50 


\begin{tabular}{|c|c|c|c|c|c|}
\hline Name & Sess & $\mathrm{Pg}$ & Name & Sess & $\mathrm{Pg}$ \\
\hline - - - - - - - - - & ---ー-- & --- & --ー-ー- & ---- & --- \\
\hline \multirow[t]{3}{*}{ Lengfellner, H. } & M6. 3 & 104 & Link, G. & $\mathrm{T} 2.3$ & 184 \\
\hline & M6. 4 & 107 & & & \\
\hline & & & Liou, R. & M8. 7 & 149 \\
\hline \multirow{2}{*}{ Leotin, $\mathrm{J}$. } & M2. 3 & 26 & & & \\
\hline & & & Lioutas, N. & $\mathrm{F} 1.7$ & 711 \\
\hline \multirow[t]{2}{*}{ Leou, K.C. } & Th8.8 & 687 & & & \\
\hline & & & Liu, C. & W1. 2 & 338 \\
\hline \multirow[t]{2}{*}{ Lesurf, J.C.G. } & $\mathrm{T} 2.8$ & 198 & & & \\
\hline & & & Liu, J.Z. & M2 . 1 & \\
\hline \multirow[t]{2}{*}{ Lesyna, L. } & M6. 2 & & & & \\
\hline & & & Liu, P. & Th1. 4 & 523 \\
\hline \multirow[t]{5}{*}{ Levush, B. } & M8. 3 & 140 & & & \\
\hline & M4. 2 & 62 & Liu, S. & M4. 8 & \\
\hline & $\mathrm{T} 4.2$ & 222 & & T3.7 & \\
\hline & W8. 8 & 511 & & & \\
\hline & W8. 7 & 508 & Liu, Songhe & T5. 12 & \\
\hline Lewis, J.M. & w3. 5 & 398 & Lorbeck, J.A. & $\mathrm{T} 7.2$ & 301 \\
\hline Lewis-Bevan, $\mathbf{W}$. & F2. 6 & 729 & Lu, w. & w2. 3 & \\
\hline Li, A. & $\mathrm{T} 3,4$ & 210 & Lu, Z.M. & $\begin{array}{l}\text { W1. } 6 \\
\text { Th6. } 5\end{array}$ & 350 \\
\hline \multirow[t]{2}{*}{$\mathrm{Li}, \mathrm{H}$} & W5. 4 & 440 & & & \\
\hline & Th 6.1 & & Lubecke, V. & W1. 4 & 344 \\
\hline \multirow[t]{2}{*}{$\mathrm{Li}, \mathrm{M}-\mathrm{Y}$} & $\mathrm{F} 1.6$ & 708 & Luhmann, N.C., Jr. & M5 . 2 & 82 \\
\hline & & & & W8. 9 & 514 \\
\hline \multirow[t]{4}{*}{ Li, S-F. } & M1. 6 & 15 & & T7. 8 & $315 a$ \\
\hline & M1. 5 & 13 & & $\mathrm{~F} 1.2$ & 696 \\
\hline & Th5.2 & 602 & & Th 8.8 & 687 \\
\hline & & & & Th 8.9 & 690 \\
\hline \multirow[t]{2}{*}{$\mathrm{Li}, \mathrm{S}$} & w5. 5 & 443 & & $\operatorname{Th} 4.7$ & 587 \\
\hline & W1. 5 & 347 & & $\operatorname{Th} 1.8$ & \\
\hline \multirow[t]{2}{*}{ Li, $x}$. & $\mathrm{T} 2.4$ & 187 & Luneville, E. & F5.1 & \\
\hline & Th2. 4 & 544 & & F 4.1 & 765 \\
\hline Li, Y. & $\operatorname{Th} 7.2$ & 650 & Lunt, B. & T5.1 & 240 \\
\hline \multirow[t]{3}{*}{ Liao, z. } & W8.1 & 493 & Luo, G.H. & W5. 2 & 434 \\
\hline & w8.1 & 493 & & & \\
\hline & & & Luo, $N$. & T2.7 & 195 \\
\hline Libelo, L.F. & W6. 6 & 470 & & W6. 1 & \\
\hline \multirow[t]{2}{*}{ Liebe, H.J. } & M3.10 & 56 & Luo, $\mathrm{X}$. & Th7. 2 & 650 \\
\hline & & & & $\operatorname{Th} 7.4$ & 654 \\
\hline \multirow[t]{2}{*}{ Lieneweg, U. } & Th 1.8 & & & & \\
\hline & & & Lutgert, $s$. & $\mathrm{T} 4.3$ & 225 \\
\hline \multirow[t]{2}{*}{ Lin, A.T. } & W8.9 & 514 & & & \\
\hline & & & Ma, C.H. & F3.5 & \\
\hline Lin, G.I. & พ8. 8 & 511 & Ma, 7 & & 356 \\
\hline Lin, $y$. & Th7. 4 & 654 & Ma, z. & Th5. 5 & 611 \\
\hline & $\operatorname{Th} 7.2$ & 650 & & & \\
\hline & & & Maaskant, P. & T5. 2 & 242 \\
\hline Lindquist, $w$. & $\operatorname{Th} 4.1$ & 568 & & & \\
\hline & & & Machuzak, J.S. & F3.3 & 750 \\
\hline
\end{tabular}

Proc. of SPIE Vol. 1514 151401-51 


\begin{tabular}{|c|c|c|c|c|c|}
\hline Name & Sess & $\mathrm{Pg}$ & Name & Sess & $\mathrm{Pg}$ \\
\hline Maeda, $\mathrm{H}$. & F3. 4 & 753 & MCMillan, R.W. & F 4.4 & 771 \\
\hline \multirow[t]{3}{*}{ Main, W. } & W4.7 & 428 & Meek, T.T. & T6.9 & 294 \\
\hline & Th8.2 & 669 & & & \\
\hline & $\operatorname{Th} 4.10$ & 596 & Mehdi, I. & T5. 6 & 254 \\
\hline Maki, N. & $\mathrm{T} 6.7$ & 288 & Meinel, H.H. & Th1.1 & 517 \\
\hline Makowski, M.A. & Th2.2 & 538 & Meng, B. & $\mathrm{T} 4.4$ & 228 \\
\hline \multirow[t]{3}{*}{ Manheimer, W.M. } & $\operatorname{Th} 8.3$ & 672 & Menzel, W. & $\operatorname{Th} 6.6$ & 634 \\
\hline & w8. 5 & 505 & & & \\
\hline & & & Messina, $A$. & $\operatorname{Th} 3.6$ & 562 \\
\hline Mania, L. & T7. 3 & & Messina, A.M. & Th 38 & \\
\hline \multirow[t]{2}{*}{ Margineda, J. } & W6. 3 & 461 & & 110.0 & \\
\hline & & & Mi, Z. & W7. 6 & \\
\hline Marr, R.A. & T1. 4 & 160 & & & \\
\hline \multirow{2}{*}{ Martin, D.H. } & Th5. 10 & 623 & Miller, D.R. & M5. 4 & 88 \\
\hline & & & Millot, P. & Th2. 6 & \\
\hline Martinez, R.D. & F1.1 & 693 & & & \\
\hline \multirow[t]{2}{*}{ Maserjian, J. } & $\operatorname{Th} 1.8$ & & Miranda, F.A. & M6.8 & \\
\hline & & & Mitsunaka, Y. & T8.2 & 318 \\
\hline Masuko, H. & M3. 2 & 41 & Miura, N. & W2. 9 & 383 \\
\hline \multirow{2}{*}{ Mathews, $H-G$. } & $\mathrm{T} 8.3$ & 321 & & & \\
\hline & & 260 & Miyoshi, M. & M7. 4 & 124 \\
\hline Matloubian, M. & T5.11 & 268 & Mobius, A. & T3.3 & 207 \\
\hline Matsuhara, $\mathrm{H}$. & M7. 2 & 120 & & w8.1 & 493 \\
\hline Matsuzawa, T. & $\mathrm{T} 6.1$ & 271 & Moeller, C.P. & T3. 5 & 213 \\
\hline Mattauch, R.J. & w3. 3 & 392 & Moeller, K.D. & $\mathrm{T} 2.6$ & 193 \\
\hline Mavergoyz, I.D. & M8. 3 & 140 & Moharram, M.A. & F 4.3 & \\
\hline McCleary, J. & M7. 7 & 132 & Moix, D. & w3.7 & 404 \\
\hline \multirow[t]{3}{*}{ Mccowan, R.B. } & Th8.5 & 678 & Molla, J. & W6. 3 & 461 \\
\hline & Th8.4 & 675 & & & \\
\hline & & & Monselesan, D. & W4. 6 & 425 \\
\hline \multirow[t]{2}{*}{ McCurdy, A.H. } & M8. 7 & 149 & & & \\
\hline & Th 4.6 & 584 & Moore, K.J. & w8. 2 & 496 \\
\hline \multirow[t]{5}{*}{ McDermott, D.B. } & w8. 9 & 514 & Moraes, J.C.S. & F2. 8 & 735 \\
\hline & T7. 8 & $315 a$ & & $\mathrm{~F} 2.7$ & 732 \\
\hline & Th8.9 & 690 & & $\operatorname{Th} 3.6$ & 562 \\
\hline & $\operatorname{Th} 8.8$ & 687 & & & \\
\hline & $\operatorname{Th} 4.7$ & 587 & Mordijck, A. & W2. 8 & 381 \\
\hline \multirow[t]{3}{*}{ McGrath, W.R. } & T5. 3 & 245 & Moretti, A. & w3. 1 & 386 \\
\hline & W1. 4 & 344 & & $\operatorname{Th} 3.6$ & 562 \\
\hline & & & & $\operatorname{Th} 3.8$ & 565 \\
\hline McKay, J.A. & W4. 4 & 419 & & F2.8 & 735 \\
\hline
\end{tabular}




\begin{tabular}{|c|c|c|c|c|c|}
\hline Name & Sess & $\mathrm{Pg}$ & Name & Sess & $\mathrm{Pg}$ \\
\hline Mori, $\mathrm{H}$. & w3.2 & 389 & $\mathrm{Ni}, \mathrm{D} . \mathrm{C}$. & M5.8 & 98 \\
\hline \multirow[t]{2}{*}{ Morimoto, M. } & M7. 4 & 124 & Nickel, $\mathrm{H}-\mathrm{U}$. & W8.1 & 493 \\
\hline & & & & W8.1 & 493 \\
\hline Morris, J.B. & $\mathrm{T} 1.4$ & 160 & & Th2.3 & 541 \\
\hline Moruzzi, G. & Th 3.4 & 556 & Nies, R. & w2. 2 & 366 \\
\hline Moss, D.G. & T5.1 & 240 & Nisenoff, $M$ & M2. 2 & 23 \\
\hline Motokawa, M. & $\mathrm{T} 6.7$ & 288 & Norajitra, P. & Th2.3 & 541 \\
\hline Mourgues, F. & Th2. 6 & & Nowak, $S$. & $\mathrm{T} 7.3$ & \\
\hline \multirow[t]{7}{*}{ Mourier, G. } & M4. 4 & 65 & Nukui, $\mathrm{K}$. & W7. 8 & 490 \\
\hline & M4. 5 & 68 & & & \\
\hline & F 4.2 & 768 & o'Brien, J. & T5. 2 & 242 \\
\hline & F5.1 & & & & \\
\hline & F 4.1 & 765 & Ochiai, S. & M3. 2 & 41 \\
\hline & F5. 2 & & & & \\
\hline & & & Ogawa, I. & F 3.2 & 747 \\
\hline \multirow[t]{2}{*}{ Muggli, P. } & W4. 2 & 413 & & & \\
\hline & & & Ohkubo, K. & T 8.3 & 321 \\
\hline \multirow{2}{*}{ Muller, G. } & M6.1 & 101 & & & \\
\hline & & & Ohm, Y. & T1.9 & 175 \\
\hline Muller, G.A. & T3.2 & & Ohta, H. & $\mathrm{T} 6.7$ & 288 \\
\hline \multirow[t]{2}{*}{ Murakami, M. } & F3. 5 & & & & \\
\hline & & & Ohyama, T. & W2. 7 & 378 \\
\hline \multirow{2}{*}{ Musyoki, s. } & M1. 4 & 10 & 40 & & \\
\hline & & & Okajima, s. & W3. 2 & 389 \\
\hline Mutho, T. & $\mathrm{T} 8.3$ & 321 & & F3. 4 & 753 \\
\hline Myasin, Y.A. & $\operatorname{Th} 6.3$ & 631 & Okamoto, $\mathrm{T}$ & $\mathrm{T} 8.2$ & 318 \\
\hline Nagashima, T. & $\mathrm{T} 8.2$ & 318 & Okazaki, Y. & $\mathrm{T} 8.2$ & 318 \\
\hline Nakamura, T. & w7. 8 & 490 & Okuda, H. & M7. 2 & 120 \\
\hline \multirow[t]{2}{*}{ Nakashima, S. } & $\mathrm{T} 6.1$ & 271 & Omar, A.S. & w5.9 & \\
\hline & & & & w1.11 & 362 \\
\hline \multirow[t]{2}{*}{ Nakazato, Y. } & M1. 4 & 10 & & w5.10 & 455 \\
\hline & & & & $\mathrm{F} 1.5$ & 705 \\
\hline Nasser, M.I. & $\mathrm{F} 4.3$ & & & & \\
\hline \multirow{2}{*}{ Neece, R.T. } & M3. 8 & 50 & No, $s$ & $\mathrm{M} 1.4$ & 10 \\
\hline & & & Orback, S. & M6. 1 & 101 \\
\hline \multirow{4}{*}{ Neikirk, D.P. } & M5. 4 & 88 & & & \\
\hline & w3. 5 & 398 & Ostdiek, P.H. & w3. 6 & 401 \\
\hline & W7. 5 & 484 & & & \\
\hline & & & Ousset, J.C. & M2. 3 & 26 \\
\hline Neilson, J. & $\mathrm{T} 8.1$ & 315 & & & \\
\hline \multirow[t]{2}{*}{ Nelson, B. } & T1.9 & 175 & Papadichev, V.A. & M8. 5 & \\
\hline & & & Papavaritis, P. & M4. 5 & 68 \\
\hline Nevins, $w$. & $\operatorname{Th} 4.1$ & 568 & & M4. 4 & 65 \\
\hline Newman, H.S. & M2. 4 & & Parail, V. & $\operatorname{Th} 4.1$ & 568 \\
\hline
\end{tabular}

Ixi ii
Proc. of SPIE Vol. 1514 151401-53 


\begin{tabular}{|c|c|c|c|c|c|}
\hline Name & Sess & $\mathrm{Pg}$ & Name & Ses's & $\mathrm{Pg}$ \\
\hline 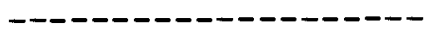 & ----- & --- & 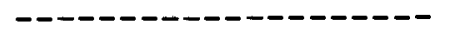 & ----- & --- \\
\hline \multirow{3}{*}{ Park, G.S. } & $\operatorname{Th} 4.2$ & 572 & Poli, L. & w3.3 & 392 \\
\hline & W4.8 & 430 & & & \\
\hline & & & Pollock, M. & M7. 7 & 132 \\
\hline Park, S.Y. & 1114.2 & Jiz & Pond, J.M. & M2. 4 & \\
\hline \multirow{2}{*}{ Parker, T.J. } & $\mathrm{T} 2.1$ & 178 & & & \\
\hline & & & Popovic, Z.B. & Th1.5 & 526 \\
\hline Parnell, W.C. & & & Poppe, U. & M6. 1 & 101 \\
\hline \multirow{3}{*}{ Pauley, R.G. } & M3. 8 & 50 & & & \\
\hline & T1. 6 & 166 & Porter, v. & W7. 4 & 481 \\
\hline & T1.2 & 155 & Portugall 0 & W2.9 & 383 \\
\hline \multirow[t]{2}{*}{ Paume, M. } & F3. 6 & 756 & & & \\
\hline & Th2. 6 & & Post, R. & $\mathrm{T} 6.6$ & 285 \\
\hline Peatman, W.B. & W3. 8 & 407 & Pradhan, M.M. & W6. 2 & 458 \\
\hline \multirow[t]{3}{*}{ Peatman, w.C.B. } & W7. 1 & 473 & Prakash, S. & T5.11 & 268 \\
\hline & w7. 3 & 478 & & & \\
\hline & & & Prentice, R. & F3.1 & 744 \\
\hline Pedrozzi, M. & W4.6 & 425 & Pretterebner, J. & T3.2 & \\
\hline \multirow[t]{2}{*}{ Peled, A. } & $\mathrm{T} 1.3$ & 158 & & T3.1 & 204 \\
\hline & & & & $\mathrm{T} 7.1$ & 298 \\
\hline Pendleton, $R$. & T8.1 & 315 & Prettl, W. & M6. 3 & 104 \\
\hline \multirow[t]{2}{*}{ Peng, S.T. } & W1. 6 & 350 & & M6. 4 & 107 \\
\hline & $\operatorname{Th} 6.5$ & & & W2. 5 & 372 \\
\hline \multirow[t]{3}{*}{ Pereira, D. } & F2.7 & 732 & Price, E. & M8. 1 & 135 \\
\hline & $\operatorname{Th} 3.6$ & 562 & & & \\
\hline & F2. 8 & 735 & Price, G. & M2.2 & 23 \\
\hline Perrin, 0 & M7. 5 & 127 & Prigent, $C$. & M3. 9 & 53 \\
\hline \multirow[t]{3}{*}{ Pershing, D.E. } & M8. 2 & 137 & Prober, D.E. & T5.10 & 265 \\
\hline & M8.1 & 135 & & & \\
\hline & M8. 6 & 146 & Puggli, P. & $\mathrm{T} 8.3$ & 321 \\
\hline Peters, S.J. & $\mathrm{F} 1.3$ & 699 & Qian, M. & W6. 5 & 467 \\
\hline Petriv, v.s. & $\operatorname{Th} 3.10$ & & Qin, X.H. & $\begin{array}{l}F 1.2 \\
\text { Th1.8 }\end{array}$ & 696 \\
\hline Pham, Q-P. & T5. 2 & 242 & Radack, D.J. & M8. 3 & 140 \\
\hline \multirow[t]{3}{*}{ Phelps, A.D.R. } & T7. 5 & 307 & & & \\
\hline & Th 8.6 & 681 & Rader, M. & M4. 7 & 74 \\
\hline & & & & $\begin{array}{l}\text { M4.6 } \\
\text { W7 } 4\end{array}$ & $\begin{array}{l}71 \\
481\end{array}$ \\
\hline Fiedr & 190.1 & $10 \perp$ & & W. & 401 \\
\hline \multirow{3}{*}{ Piosczyk, B. } & W8. 3 & 499 & Radkevich, A.O. & Th 3.1 & \\
\hline & W8.1 & 493 & & Th3.7 & \\
\hline & W8.1 & 493 & & $\operatorname{Th} 3.10$ & \\
\hline \multirow[t]{2}{*}{ Plant, D.V. } & M5. 8 & 98 & Rai, J. & F2.9 & 738 \\
\hline & T5.11 & 268 & Rai, S. & F2.9 & 738 \\
\hline
\end{tabular}

Proc. of S局区 ì이. 1514 151401-54 


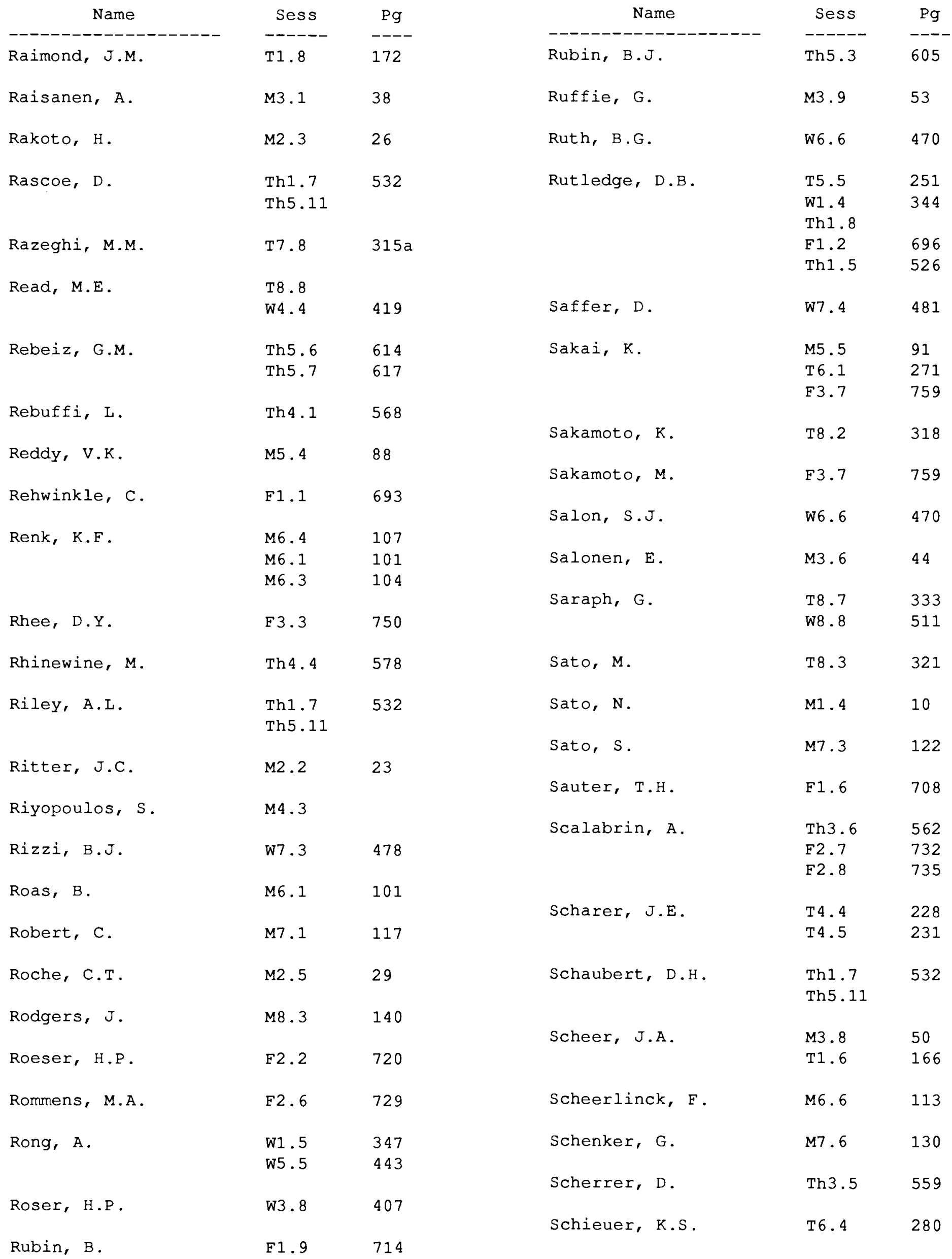

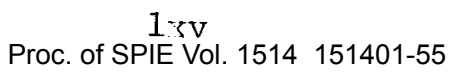




\begin{tabular}{|c|c|c|c|c|c|}
\hline Name & Sess & $\mathrm{Pg}$ & Name & Sess & $\mathrm{Pg}$ \\
\hline Schlesinger, $\mathrm{z}$. & M2. 1 & & Sironi, M. & $\operatorname{Th} 4.1$ & 568 \\
\hline Schneider, G. & M6. 3 & 104 & Sirotinskii, O.I. & M6. 7 & 116 \\
\hline Schnellbogl, A. & M6. 4 & 107 & Sjogren, L.B. & $\begin{array}{l}\text { F1.2 } \\
\text { Th1.8 }\end{array}$ & 696 \\
\hline Schotzau, H.J. & Th7 7.5 & 655 & Skatrud, D.D. & $\operatorname{Th} 3.3$ & 553 \\
\hline Schultz, L. & M6.1 & 101 & Skelton, E.F. & M2. 3 & 26 \\
\hline Schunemann, $K$. & $\begin{array}{l}\text { M1. } 7 \\
\text { W5.9 }\end{array}$ & 17 & Skipec, M. & W8. 6 & \\
\hline Schutzmann, J. & M6. 1 & 101 & Skopec, M. & Th 4.5 & 581 \\
\hline Schwaab, G.W. & $\begin{array}{l}\text { W3. } 8 \\
\text { F2.2 } \\
\text { F2.3 }\end{array}$ & $\begin{array}{l}407 \\
720 \\
723\end{array}$ & Solari, G. & T7.3 & \\
\hline Schwab, W. & Th 6.6 & 634 & Soln, J. & $\mathrm{T} 4.6$ & 234 \\
\hline Scott, D.C. & M5. 8 & 98 & Soltner, $\mathrm{H}$. & M6. 1 & 101 \\
\hline Seals, J. & M3. 8 & 50 & Sonoda, S. & $\mathrm{T} 6.1$ & 271 \\
\hline Sealy, P.J. & T3. 6 & 216 & Soulen, R.J., Jr. & M2. 3 & 26 \\
\hline Seashore, C.R. & $\operatorname{Th} 1.2$ & & Souza, J.R. & $\mathrm{w} 1.10$ & 359 \\
\hline Shaw, L. & $\begin{array}{l}\text { T1.9 } \\
\text { Th1.4 }\end{array}$ & $\begin{array}{l}175 \\
523\end{array}$ & $\begin{array}{l}\text { Souza, R.M.De F. } \\
\text { Spark, S.N. }\end{array}$ & $\begin{array}{l}\text { W1. } 7 \\
\text { T7. } 5\end{array}$ & $\begin{array}{l}353 \\
307\end{array}$ \\
\hline Shen, S.C. & $\begin{array}{l}\mathrm{T} 2.7 \\
\mathrm{~W} 6.1\end{array}$ & 195 & Spencer, T.A. & $\begin{array}{l}\text { Th8. } 6 \\
\text { M8. } 4\end{array}$ & $\begin{array}{l}681 \\
143\end{array}$ \\
\hline Shi, J-M. & F1.8 & & Stallard, B.W. & Th2.2 & 538 \\
\hline Shibai & M7.2 & 120 & Stesmans, A. & M6. 6 & 113 \\
\hline Shimabukuro, F.I. & W6.7 & & Streit, D. & Th1. 4 & 523 \\
\hline Shin, P.S. & W6. 6 & 470 & Striffler, C.D. & W4.7 & 428 \\
\hline Sholley, M. & $\begin{array}{l}\text { T1.9 } \\
\text { Th1.4 }\end{array}$ & $\begin{array}{l}175 \\
523\end{array}$ & & $\begin{array}{l}\text { Th8.2 } \\
\text { Th } 4.10\end{array}$ & $\begin{array}{l}669 \\
596\end{array}$ \\
\hline Silos Morase, J.C. & $\operatorname{Th} 3.4$ & 556 & Strom, U. & M2. 4 & \\
\hline Singh, A. & $\mathrm{T} 8.7$ & 333 & Strumia, $F$. & $\begin{array}{l}\text { W3.1 } \\
\text { Th3.4 }\end{array}$ & $\begin{array}{l}386 \\
556\end{array}$ \\
\hline Singh, R.P. & W1.9 & & & $\begin{array}{l}\text { Th3 } .6 \\
\text { Th3.8 }\end{array}$ & $\begin{array}{l}562 \\
565\end{array}$ \\
\hline Singh, $v$. & W6. 2 & 458 & & F2. 8 & 735 \\
\hline Singh, V.R. & W6.2 & 458 & $\mathrm{Su}, \mathrm{J}$. & $\begin{array}{l}\text { T2.9 } \\
\text { W6.5 }\end{array}$ & $\begin{array}{l}201 \\
467\end{array}$ \\
\hline Sinilschikova, I.V. & M8. 5 & & & Th7.9 & 661 \\
\hline
\end{tabular}




\begin{tabular}{|c|c|c|c|c|c|}
\hline Name & Sess & $\mathrm{Pg}$ & Name & Sess & $\mathrm{Pg}$ \\
\hline Sugawara, T. & $\mathrm{T} 8.2$ & 318 & Titz, R.U. & W3.8 & 407 \\
\hline Sullivan, C.A. & $\begin{array}{l}\text { Th8.4 } \\
\text { Th8.3 }\end{array}$ & $\begin{array}{l}675 \\
672\end{array}$ & Tiwari, A.K. & W1. 9 & \\
\hline Sultan, N. & M5. 6 & 94 & Tolmunen, T.J. & $\begin{array}{l}\text { M5.1 } \\
\text { T5.5 }\end{array}$ & $\begin{array}{l}79 \\
251\end{array}$ \\
\hline Sun, L. & W5.7 & 449 & Tran, M.Q. & $\begin{array}{l}\text { W4.1 } \\
\text { T8.3 }\end{array}$ & $\begin{array}{l}410 \\
321\end{array}$ \\
\hline Swain, D. & $\operatorname{Th} 4.1$ & 568 & & $\begin{array}{l}\text { W4.6 } \\
\text { W4.2 }\end{array}$ & $\begin{array}{l}425 \\
413\end{array}$ \\
\hline Takaba, H. & M7. 4 & 124 & & Th2.1 & 535 \\
\hline Takahashi, H. & F3. 4 & 753 & Tran, T.M. & $\begin{array}{l}\text { W4.2 } \\
\text { W4.6 }\end{array}$ & $\begin{array}{l}413 \\
425\end{array}$ \\
\hline Takami, $\mathrm{H}$. & M7. 3 & 122 & & $\begin{array}{l}\text { T8.3 } \\
\text { Th2.1 }\end{array}$ & $\begin{array}{l}321 \\
535\end{array}$ \\
\hline Takeyama, S. & W2. 9 & 383 & Tremeau, $\mathrm{T}$. & M4. 4 & 65 \\
\hline Talvard, M. & Th2.8 & 548 & Tretyakov, V.E. & Th7.7 & \\
\hline $\operatorname{Tan}, \mathrm{K}$ & T1. 9 & 175 & Trussel, C.W. Jr. & F 4.4 & 771 \\
\hline Tan, M. & T1.9 & 175 & Tsai, Y.Y. & w5. 10 & 455 \\
\hline Tanaka, M. & M7.3 & 122 & & F1. 5 & 705 \\
\hline Tang, $\mathrm{H}$. & M6. 5 & 110 & Tsao, A.J. & M5 . 4 & 88 \\
\hline Tantawi, S. & Th 4.10 & 596 & Tsirulnikov, M. & $\mathrm{T} 8.1$ & 315 \\
\hline Tatsukawa, T. & F 3.2 & 747 & Tudisco, 0. & Th2 .7 & \\
\hline Telles, E.M. & Th3.6 & 562 & Tulyakov, N.N. & Th7.7 & \\
\hline Telyatnikov, A.L. & $\begin{array}{l}\operatorname{Th} 3.10 \\
\operatorname{Th} 3.1\end{array}$ & & Ugras, N.G. & $\mathrm{T} 5.10$ & 265 \\
\hline & Th3 .7 & & Ulmet, J.P. & M2. 3 & 26 \\
\hline Temkin, R.J. & $\begin{array}{l}\text { M4. } 5 \\
\text { M8. } \\
\text { M4. } 4\end{array}$ & $\begin{array}{l}68 \\
149 \\
65\end{array}$ & Unrau, U.B. & $\begin{array}{l}\text { T2.5 } \\
\text { Th7.8 }\end{array}$ & $\begin{array}{l}190 \\
658\end{array}$ \\
\hline & $\begin{array}{l}\text { T3.4 } \\
\text { W4.3 }\end{array}$ & $\begin{array}{l}210 \\
416\end{array}$ & Urban, $\mathrm{K}$. & M6. 1 & 101 \\
\hline & T8. 5 & 327 & Valmu, $\mathrm{H}$ & M3. 1 & 38 \\
\hline & T 8.4 & 324 & & & \\
\hline & $\operatorname{Th} 4.3$ & 575 & van Klarenbosch, A. & W2 . 4 & 369 \\
\hline Thomas, H.J. & T1.7 & 169 & VanBockstal, L. & M6. 6 & 113 \\
\hline Thumm, M. & $\begin{array}{l}\text { T3.1 } \\
\text { T3.2 }\end{array}$ & 204 & Vandersluis, K.L. & F3. 5 & \\
\hline & $\begin{array}{l}\text { T7.1 } \\
\text { T7.8 }\end{array}$ & $\begin{array}{l}298 \\
315 a\end{array}$ & Vassenden, $F$. & M6. 1 & 101 \\
\hline & W5. 4 & 440 & Vernon, R.J. & T3. 6 & 216 \\
\hline & w5. 3 & 437 & & $\begin{array}{l}\text { W5 } 2 \\
\text { T } 7.2\end{array}$ & $\begin{array}{l}434 \\
301\end{array}$ \\
\hline
\end{tabular}

Ting, A.C.

Th8.3 672

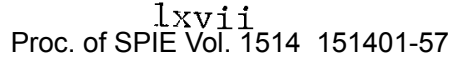




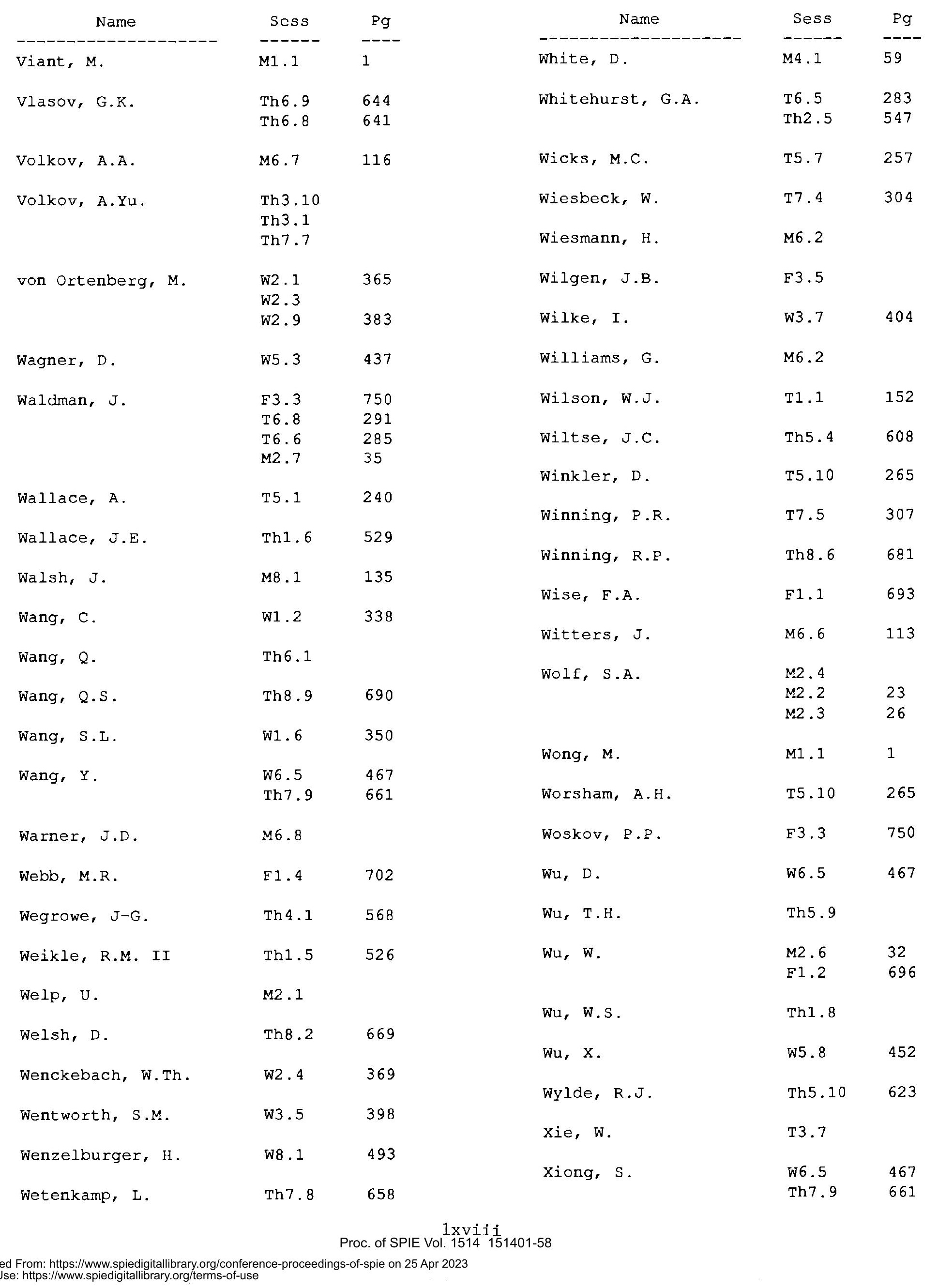




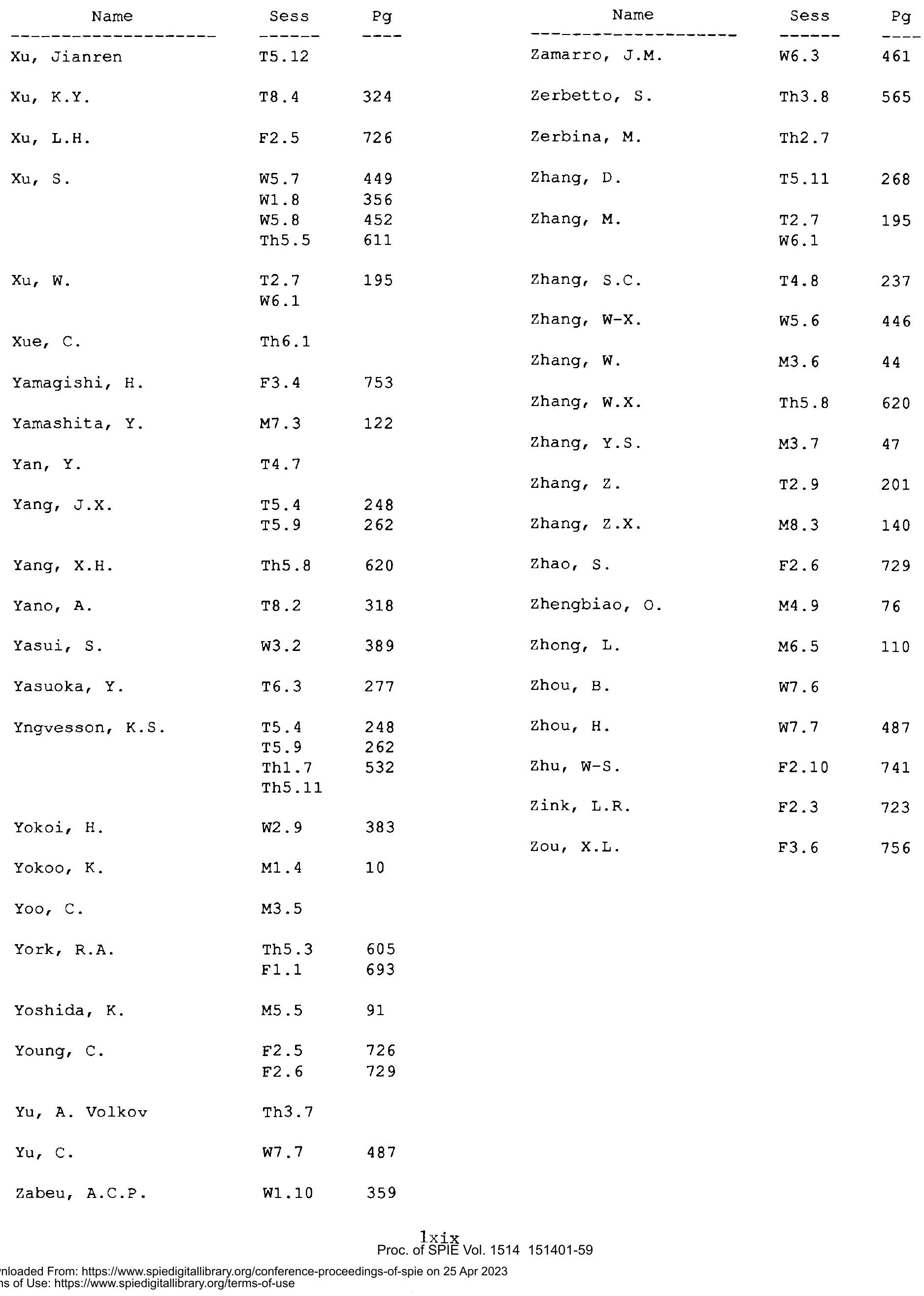

